Measuring the Distributional Impact of Taxation and Public Spending: The Practice of Fiscal Incidence Analysis

Nora Lustig

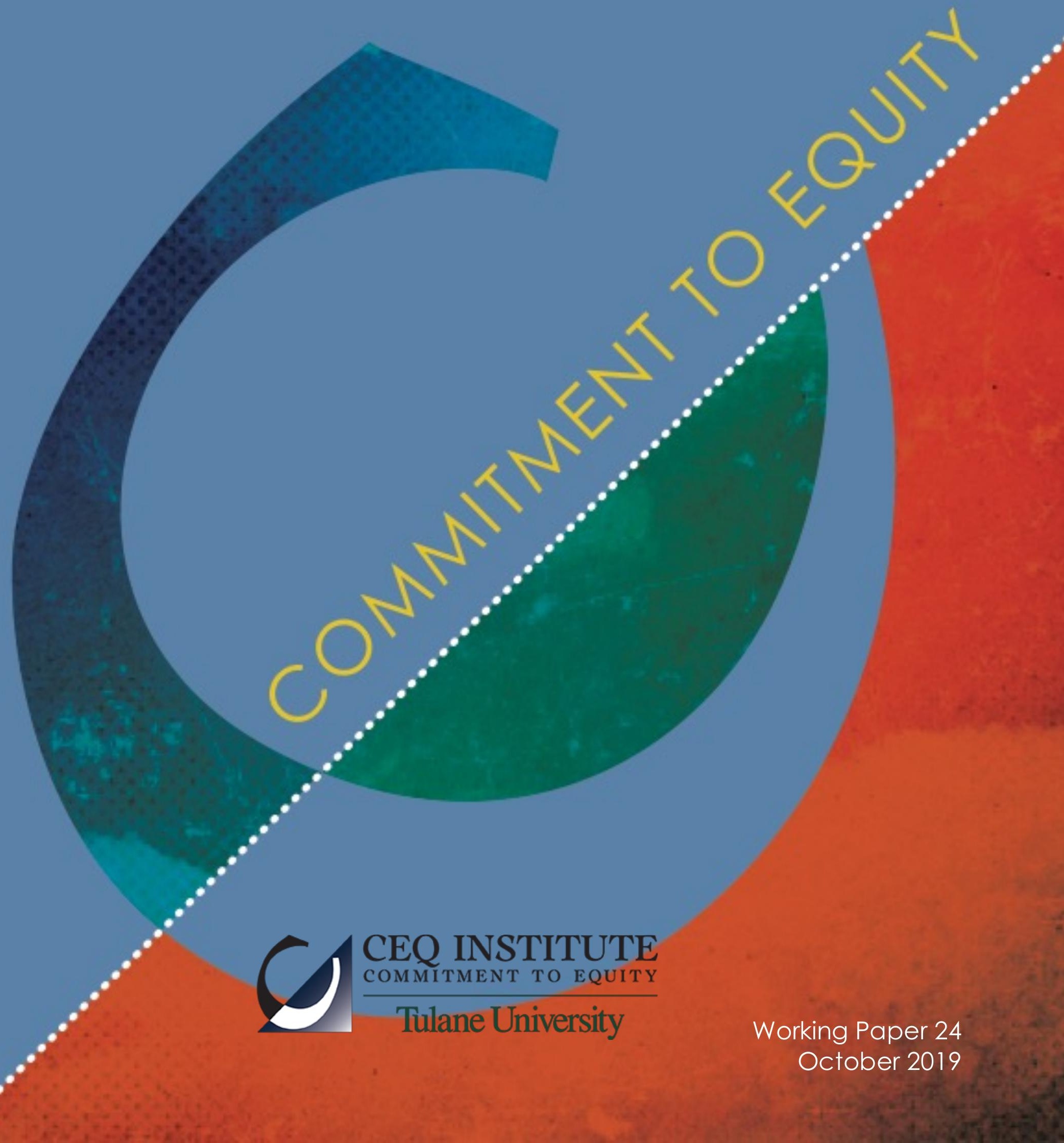




\section{The CEQ Working Paper Series}

The CEQ Institute at Tulane University works to reduce inequality and poverty through rigorous tax and benefit incidence analysis and active engagement with the policy community. The studies published in the CEQ Working Paper series are pre-publication versions of peer-reviewed or scholarly articles, book chapters, and reports produced by the Institute. The papers mainly include empirical studies based on the CEQ methodology and theoretical analysis of the impact of fiscal policy on poverty and inequality. The content of the papers published in this series is entirely the responsibility of the author or authors. Although all the results of empirical studies are reviewed according to the protocol of quality control established by the CEQ Institute, the papers are not subject to a formal arbitration process. Moreover, national and international agencies often update their data series, the information included here may be subject to change. For updates, the reader is referred to the CEQ Standard Indicators available online in the CEQ Institute's website www.commitmentoequity.org/datacenter. The CEQ Working Paper series is possible thanks to the generous support of the Bill \& Melinda Gates Foundation. For more information, visit www.commitmentoequity.org.

The CEQ logo is a stylized graphical representation of a Lorenz curve for a fairly unequal distribution of income (the bottom part of the $\mathrm{C}$, below the diagonal) and a concentration curve for a very

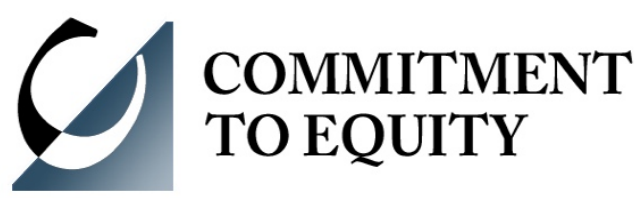
progressive transfer (the top part of the $\mathrm{C}$ ). 


\section{G CEQ INSTITUTE \\ COMMITMENT TO EQUITY \\ Tulane University}

\section{MEASURING THE DISTRIBUTIONAL IMPACT OF TAXATION AND PUBLIC SPENDING: THE PRACTICE OF FISCAL INCIDENCE ANALYSIS}

Nora Lustig*

CEQ Working Paper 24

OCTOBER 2019

\begin{abstract}
Taxation and public spending are key policy levers the state has in its power to change the distribution of income. One of the most commonly used methods to measure the distributional impact of a country's taxes and public spending is fiscal incidence analysis. Rooted in the field of Public Finance, fiscal incidence analysis is the method utilized to allocate taxes and public spending to households so that one can compare incomes before taxes and transfers with incomes after them. Standard fiscal incidence analysis just looks at what is paid and what is received without assessing the behavioral responses that taxes and public spending may trigger on individuals or households. This is often referred to as the "accounting approach." Although the theory is quite straightforward, its application can be fraught with complications. The salient ones are discussed here. While ignoring behavioral responses and general equilibrium effects is a limitation of the accounting approach, the effects calculated with this method are considered a reasonable approximation of the short-run welfare impact. Fiscal incidence analysis, however, can be designed to include behavioral responses as well as general equilibrium and inter-temporal effects. This article focuses on the implementation of fiscal incidence analysis using the accounting approach.
\end{abstract}

JEL Codes: D31, H22, I32, I38

Keywords: Fiscal incidence, taxation, social spending, transfers, pensions, progressivity, distributional effects, inequality, poverty, marginal contribution, effectiveness, valuing in-kind transfers.

\footnotetext{
* This his is a draft of an article that has been commissioned for publication by Oxford University Press as part of the Oxford Research Encyclopedia of Economics and Finance, https://oxfordre.com/economics. I would like to thank Steven Sheffrin and two anonymous reviewers for very useful comments on an earlier draft. All remaining errors and omissions are my sole responsibility.
} 


\title{
Measuring the Distributional Impact of Taxation and Public Spending: The Practice of Fiscal Incidence Analysis ${ }^{1}$ \\ Nora Lustig
}

\begin{abstract}
Taxation and public spending are key policy levers the state has in its power to change the distribution of income. One of the most commonly used methods to measure the distributional impact of a country's taxes and public spending is fiscal incidence analysis. Rooted in the field of Public Finance, fiscal incidence analysis is the method utilized to allocate taxes and public spending to households so that one can compare incomes before taxes and transfers with incomes after them. Standard fiscal incidence analysis just looks at what is paid and what is received without assessing the behavioral responses that taxes and public spending may trigger on individuals or households. This is often referred to as the "accounting approach." Although the theory is quite straightforward, its application can be fraught with complications. The salient ones are discussed here. While ignoring behavioral responses and general equilibrium effects is a limitation of the accounting approach, the effects calculated with this method are considered a reasonable approximation of the short-run welfare impact. Fiscal incidence analysis, however, can be designed to include behavioral responses as well as general equilibrium and inter-temporal effects. This article focuses on the implementation of fiscal incidence analysis using the accounting approach.
\end{abstract}

Keywords: fiscal incidence, taxation, social spending, transfers, pensions, progressivity, distributional effects, inequality, poverty, marginal contribution, effectiveness, valuing in-kind transfers.

JEL: D31, H22, I32, I38

\section{Introduction}

Taxation and public spending are key policy levers the state has in its power to change the distribution of income determined both by market forces and institutions, and the prevailing distribution of wealth and property. ${ }^{2}$ Two key indicators of society's commitment to equalizing opportunities and reducing poverty and social exclusion are the share of total income devoted to social spending and how equalizing and pro-poor this spending is. ${ }^{3}$ While measuring the level of taxation and spending (in absolute terms or as a share of GDP) is straightforward, determining their impact on inequality and poverty is more complex.

\footnotetext{
1 This is a draft of an article that has been commissioned for publication by Oxford University Press as part of the Oxford Research Encyclopedia of Economics and Finance, https://oxfordre.com/economics. I would like to thank Steven Sheffrin and two anonymous reviewers for very useful comments on an earlier draft. All remaining errors and omissions are my sole responsibility.

2 See, for example, Atkinson (2015), Barr (2012), Bourguignon and Pereira da Silva (2003), Musgrave (1959), Lindert (1994, 2004) and Piketty (2014). Government activity affects the distribution of income and wealth through a variety of channels: public spending, taxation, borrowing, macroeconomic policy, foreign policy, competition policy, regulatory activities, ownership or control of business enterprises, and norms and institutions.

3 Barr (2012) and Lindert (2004).
} 
Rooted in the field of Public Finance, fiscal incidence analysis is one of the most commonly used methods to measure the distributional impact of a country's taxes and public spending. Fiscal incidence analysis is designed to measure who bears the burden of taxes and who receives the benefits of government spending-in particular, of social spending--, and who are the gainers and losers of particular tax reforms or changes to welfare programs. In practice, fiscal incidence analysis is the method utilized to allocate taxes and public spending to households so that one can compare incomes before taxes and transfers with incomes after them. ${ }^{4}$

Fiscal incidence analysis can be used to assess the redistributive impact of a fiscal system as a whole or changes of specific fiscal instruments (e.g., eliminating tax exemptions or raising the VAT rate). In particular, fiscal incidence analysis is used to address the following questions: Who bears the burden of taxation and who receives the benefits of public spending? How much income redistribution is being accomplished through taxation and public spending? What is the impact of taxation and public spending on poverty and the poor? How equalizing are specific taxes and government welfare programs? How progressive are spending on education and health? How effective are taxes and government spending in reducing inequality and poverty? Who are the losers and winners of tax and welfare programs reforms? Real time analysis of the winners and losers, in fact, plays an important role in shaping the policy debate, for example, in France, ${ }^{5}$ the United Kingdom, ${ }^{6}$ and the United States. ${ }^{7}$

\footnotetext{
${ }^{4}$ Among taxes, typical ones that appear in fiscal incidence analysis are personal income tax, payroll taxes, corporate taxes (however, they are not always included), other direct taxes such as property taxes, VAT, sales taxes and excise taxes. On the spending side, cash and near-cash transfers, education, health, and housing spending, and consumption subsidies.

${ }^{5}$ In France, this type of analysis takes place at the Institut des Politiques Publiques (IPP) of the Paris School of Economics. In its website, the institute states: "IPP researchers are particularly concerned with household taxation, issues around local public finance, corporate taxation, poverty reduction, policies targeting families, wealth taxation and inheritance, and more generally the architecture of our tax and transfer system. The purpose is to assess the impact of reforms which have already been implemented or are simply being considered, from the standpoint of their efficiency as well as of their redistributive impact." https://www.ipp.eu/en/topics/tax-and-social-system/

${ }^{6}$ In the United Kingdom, the leading organization is the Institute for Fiscal Studies (IFS). In its website, the IFS states: "Since its foundation in the 1960s, the IFS has studied the design of the UK's tax and benefit system, and the effects it has on individuals and companies. This continues to be a core part of the Institute's work. We monitor and analyse policy developments and proposals on an ongoing basis and use this work to make important contributions to public debates. Each year in the run up to the Budget we publish our own Green Budget, which addresses the challenges facing the Chancellor, and we publish analysis of policy changes immediately following the Budget and fiscal statements. More recently we have also began supporting the analysis of tax policy in developing countries, including via our TaxDev initiative."

https://www.ifs.org.uk/research areas/116?year published[start]=\&year published[end]=\&page=1\&

${ }^{7}$ In the United States, the leading organization is the Urban-Brookings Tax Policy Center (TPC). In its website, the TPC states: "The Urban-Brookings Tax Policy Center (TPC) aims to provide independent analyses of current and longer-term tax issues and to communicate its analyses to the public and to policymakers in a timely and accessible manner. The Center combines top national experts in tax, expenditure, budget policy, and microsimulation modeling to concentrate on four overarching areas of tax policy that are critical to future debate. TPC is a joint venture of the Urban Institute and Brookings Institution. The Center is made up of nationally recognized experts in tax, budget, and social policy who have served at the highest levels of government. TPC provides timely, accessible analysis and facts about tax policy to policymakers, journalists, citizens, and researchers. To read the full collection of research or find out about news and events, visit the Center's website at: http://www.taxpolicycenter.org/“"
} 
The tax incidence literature includes a long list of studies going back to the middle of the XXth century-mainly on the US tax system--starting with the pioneer work of Musgrave et al. (1951) and Musgrave (1959), and the Tax Foundation (1960); and, subsequently, by Musgrave, Case, and Leonard (1974), Pechman and Okner (1974), and Musgrave and Musgrave (1976). On the expenditure side, early studies on its incidence can be found in Peacock (1954), Gillespie (1965), and the Tax Foundation (1967). ${ }^{8}$ To this early work one should add, for example, Urrutia and de Sandoval (1976), Meerman, (1979) and Selowsky (1979) who analyzed the incidence of public spending in Colombia, Malaysia, and Colombia, respectively. ${ }^{9}$

From a policy viewpoint, net fiscal incidence (that is, taxes net of transfers) is the relevant measure that government authorities need to use in judging the fiscal system as a whole or particular policies. Focusing on one side of the ledger of fiscal accounts can be seriously misleading. For instance, taxes may well be progressive (and equalizing) but, if the poor pay taxes and the amount they receive in transfers is not large enough to more than compensate for the taxes they pay, a progressive fiscal system may worsen poverty. ${ }^{10}$ An increase in value added taxes (VAT) may be rejected on equity grounds as being regressive, but it actually may be desirable if the resulting revenues are used to finance cash transfers to the poor or primary-school services in poor neighborhoods. Expanding social protection benefits such as pensions to low income groups may help combat old-age poverty. However, if this expansion needs to be financed with higher consumption taxes, a significant portion of the poor who are not eligible for pension benefits could be left worse off (at least, in the present). ${ }^{11}$

The simplest version of fiscal incidence analysis just looks at what is paid and what is received without assessing the behavioral responses that taxes and public spending may trigger on individuals or households. This is often referred to as the "accounting approach." This approach takes private income as given and allocates taxes and public spending to individuals and families in different economic circumstances according to certain assumptions. Available fiscal incidence studies that use the accounting approach, however, are not a mechanically applied accounting exercise. They analyze

\footnotetext{
8 The Tax Foundation (1967) study, actually, looks at both taxes and expenditures. In some tax incidence work, taxes are measured as taxes net of cash transfers.

${ }^{9}$ For a description, applications and limitations of standard incidence analysis as well as of those which include behavioral responses and general equilibrium effects, see the items marked with an "** in the References section. The readings mentioned in the references section and in the above paragraph are neither meant to be an exhaustive list nor represent the history of thought in fiscal incidence analysis. The list is meant to give the reader a sample of references to early work on fiscal incidence analysis as well as of its evolution.

10 See the results in Lustig (2018b) and Figure 4 above.

11 For recent studies which look at both the tax (both direct and indirect) and spending side (both cash and in-kind transfers), see, for example, Alam, Inchauste, and Serajuddin (2017); Aristy-Escuder et al. (2018); Arunatilake, Inchauste, and Lustig (2017); Beneke, Lustig, and Oliva (2018); Bucheli et al. (2014); Cabrera, Lustig, and Morán (2015); Cancho and Bordarenko (2017); Enami (2018a); Higgins and Lustig (2016); Higgins and others (2016); Higgins and Pereira (2014); Hill and others (2017); Inchauste and Lustig (2017); Inchauste and others (2017); Jaramillo (2014); Jellema, Wai-Poi, and Afkar (2017) ; Jellema and others (2018); Jouini and others (2018); Lopez-Calva and others (2017) ; Lustig (2015, 2016, 2018a, 2018b); Lustig, Pessino, and Scott (2014); Martínez et al. (2018); Paz-Arauco et al. (2014); Rossignolo (2018); Scott (2014); Younger and Khachatryan (2017); Younger, Myamba, and Mdadila (2016); Younger, Osei-Assibey, and Oppong (2017); Younger (2018). Also, see the CEQ Working Paper series available at www.commitmentoequity.org. In these studies, the reader will find examples of how the purchasing power of the poor may be lowered by fiscal policy even if the combined effect of taxes, transfers, and subsidies is equalizing.
} 
the incidence of taxes by their assumed economic rather than statutory incidence (i.e., where a tax is proximately levied). The economic incidence, strictly speaking, depends on the elasticity of demand and supply of factors and goods, and the ensuing general equilibrium effects. In essence, the accounting approach implicitly assumes zero (completely inelastic) demand price and labor supply elasticities which may not be far-fetched assumptions for analyzing effects in the short-run. Under these assumptions, individual income taxes and contributions (both by employee and employer) are borne by labor in the form of lower wages, taxes on incomes from capital are borne by the owners, and indirect taxes (on both final goods and inputs, using input-output tables for the latter) are fully shifted forward to consumers in the form of higher prices.

On the transfers side, fiscal incidence studies assume that transfers do not induce individuals to work less than in the absence of transfers: that is, labor supply is assumed to be perfectly inelastic to an increase in non-work income (i.e., studies assume zero non-work income elasticity in labor supply). In addition, fiscal incidence studies-- especially those for low- and middle-income countries-- often take into account the lower incidence associated with consumption of own-production (quite common, especially in rural areas in developing countries), informality and other forms of tax evasion due to corruption or poor enforcement schemes. While ignoring behavioral responses and general equilibrium effects is a limitation of the accounting approach, the effects calculated with this method are considered a reasonable approximation of the short-run welfare impact. ${ }^{12}$

Fiscal incidence analysis, however, can be designed to include behavioral responses and general equilibrium effects. It can be point-in-time or lifetime fiscal incidence analysis. That is, the analysis can assess a current system or estimate the potential or actual effects of particular reforms taking into consideration the lifetime earnings profiles. The analysis can assess the average incidence of a tax or benefit or it can assess the incidence on the margin. For example, although the average incidence of primary education spending in a low-income country may show that the main beneficiaries are from urban areas, expanding this spending could benefit the rural (poorer) population making the marginal incidence more progressive than the average..$^{13}$

This article focuses on the implementation of fiscal incidence analysis using the accounting approach which is the most commonly used framework in practice. In particular, the article presents fiscal incidence's conceptual components and assumptions, discusses the data requirements and their challenges, and describes the main indicators and their properties illustrating with examples.

\footnotetext{
${ }^{12}$ Coady and others, for instance, state "The first order estimate is much easier to calculate, provides a bound on the realincome effect, and is likely to closely approximate a more sophisticated estimate. Finally, since one expects that short-run substitution elasticities are smaller than long-run elasticities, the first-order estimate will be a better approximation of the short-run welfare impact." (Coady and others, 2006, p. 9).

${ }^{13}$ For examples of fiscal incidence analysis in a partial equilibrium context see Coady (2006); Gertler and Glewwe (1990); Gertler and van der Gaag (1990); van de Walle (1998 and 2003); and, Younger and others (1999). Devarajan and Hossein (1998) carry out fiscal incidence analysis in a general equilibrium framework. Fiscal incidence analysis in an intertemporal setting for the United States can be found in Fullerton and Rogers (1991) and Slemrod (1992). An application of the marginal incidence analysis is presented in Younger (2003) and van de Walle (2003), for example.
} 


\section{Fiscal Incidence Analysis in Practice: Allocating Taxes and Transfers to Households}

\section{Constructing the Core Income Concepts: The Bedrock of Fiscal Incidence Analysis}

As mentioned above, in the accounting approach there are no behavioral responses, no general equilibrium effects and no dynamic effects associated with tax and transfers policy. In other words, the counterfactual income in the presence of a tax (transfer) is simply the prefiscal income minus (plus) the tax (transfer). Once the allocation judgments have been made, who bears the burden (receives the benefit) of a tax (transfer) in the accounting framework is altogether straightforward. Thus, the building block of fiscal incidence analysis is the construction of "income concepts." That is, starting from a prefiscal income concept or market income (mainly, income from labour and capital and private transfers), each new income concept is constructed by adding the relevant transfers and subsidies and subtracting taxes to the previous income concept. For example, to obtain the concept of disposable income, one needs to subtract direct personal income taxes and add cash transfers to market income; consumable income is generated by subtracting indirect (consumption) taxes and adding subsidies to disposable income; and, final income is obtained by adding government spending on education and health to consumable income. ${ }^{14}$ A schematic presentation of this process can be seen in Figure $1 .{ }^{15}$ Recall that in the accounting approach no claim is made that the original or market income equals the true counterfactual income in the absence of taxes and transfers. It is a first-order approximation.

\footnotetext{
${ }^{14}$ In other words, let's define the before taxes and transfers income of unit $b$ as $I_{b}$ (i.e., a household's per capita income) and net taxes of type $i$ as $T_{i}$. Let's define the "allocator" of tax $i$ to unit $b$ as $S_{i b}$ (or the share of net tax $i$ borne by unit $b$ ). Then, post-tax income of unit $b$ can be defined as: $Y_{b}=I_{b}-\sum_{\mathrm{i}} T_{i} S_{i h .}$

15 The income concepts are named using the terminology in Lustig (2018a).
} 
Figure 1: Construction of Income Concepts

BENEFITS

\section{Market Income}

Wages and salaries, income from capital, private transfers (remittances, private pensions, etc.) before taxes, social security contributions and government transfers [AND plus contributory social insurance old-age pensions minus contributions to old-age pensions ONLY in the case in which pensions are treated as pure deferred or replacement income]
TAXES

Direct cash and near cash transfers: conditional and unconditional cash transfers, school feeding programs, free food transfers, etc. [AND plus contributory social insurance old-age pensions ONLY in the case that contributory pensions are treated as transfers]

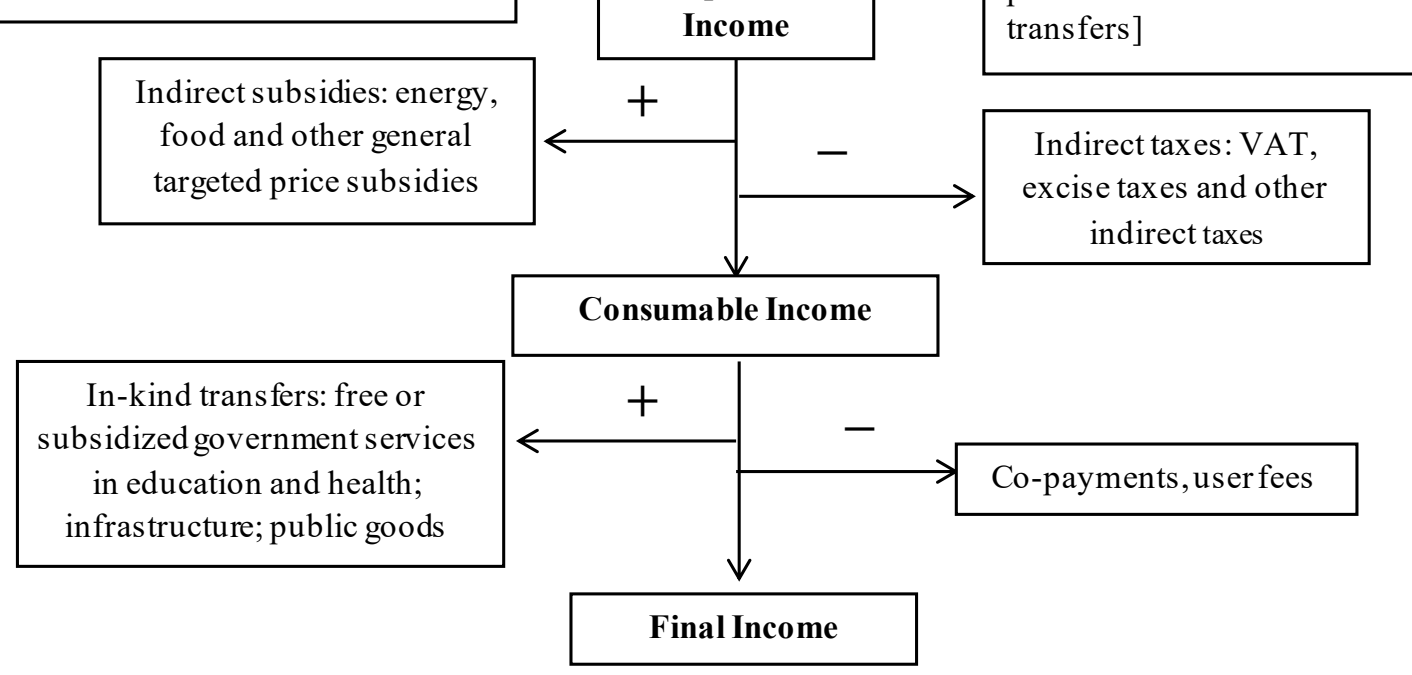

Source: Lustig and Higgins (2018), Figure 1-1. 
Not all the fiscal incidence studies construct the four income concepts shown in Figure $1 .{ }^{16}$ For instance, EUROMOD at the University of Essex presents results for European Union member countries up to disposable income only. ${ }^{17}$ So does the OECD Income Distribution Database for members of the organization. In contrast, the Commitment to Equity (CEQ) Institute at Tulane University presents results for a considerable number of low-and middle-income countries for all four income concepts. ${ }^{18}$ Disposable income or consumption (per capita or equivalized) is the standard welfare indicator used to measure poverty and inequality in international databases, ${ }^{19}$ official statistics, and the bulk of poverty and inequality research. However, actual consumption of goods and services will be different if, for example, consumption taxes on food are exempt in one country (or period) but pay VAT in another country (or period) even if disposable income is identical. Hence the importance of the concept of consumable income as an indicator of household welfare. ${ }^{20}$ Similarly, if in one country households have access to free publicly provided education and health services while in another country they don't, welfare levels will be different. Hence the importance of the concept of final income as an indicator of welfare. ${ }^{21}$

\section{Data Requirements and Data Challenges}

Identifying who bears the burden of taxes and who benefits from government spending, or who the winners and losers of particular fiscal reforms are, requires the use of household-level data. Fiscal incidence studies use microdata from household surveys combined with budget data from fiscal accounts and other administrative registries. The data requirements for a fiscal incidence analysis includes three main ingredients: a recent household survey (possible options: expenditure-income, expenditure, employment, Living Standard Measurement Surveys, and so on) representative at the

\footnotetext{
${ }^{16}$ Some studies do not attempt to calculate the income concepts and focus on the incidence of specific fiscal instruments. For example, see LATAX--a multi-country flexible tax micro-simulation model--, housed in the Institute of Fiscal Studies. (Abramovsky, Laura and David Phillips, 2015).

(http://www.ifs.org.uk/uploads/publications/software/LATAX/LATAX\%20Manual.pdf). LIS (the Luxembourg Income Study) presents indicators for market and disposable income only. ), http://www.lisdatacenter.org/our-data/lwsdatabase/

${ }^{17}$ For more details, see https://www.euromod.ac.uk/.

18 See http://www.commitmentoequity.org/. "Final income" in CEQ studies, however, does not include the incidence of infrastructure spending or spending on other public goods (broadly defined). The CEQ definition of final income is similar to the concept of adjusted disposable income proposed by the Canberra Group Handbook (CGH) on Household Income Statistics except for a crucial difference: the latter does not subtract net indirect taxes from disposable income (United Nations Economic Commission for Europe, 2011).

19 See, for example, the following international databases: CEPALSTAT (UN Economic Commission for Latin America and the Caribbean), http://estadisticas.cepal.org/cepalstat/WEB_CEPALSTAT/Portada.asp; IDD (Income Distribution Database/OECD), http://www.oecd.org/social/income-distribution-database.htm; LIS/LWS (Luxembourg Income Study), http://www.lisdatacenter.org/our-data/lws-database/; PovcalNet (World Development Indicators, World Bank), http://iresearch.worldbank.org/PovcalNet/povOnDemand.aspx; SEDLAC (Socio-Economic Database for Latin America and the Caribbean/CEDLAS at Universidad Nacional de La Plata and World Bank), http://sedlac.econo.unlp.edu.ar/; WIID (World Income Inequality Database/UNU-WIDER), https://www.wider.unu.edu/project/wiid-world-income-inequality-database.

${ }^{20}$ See discussion in Higgins and Lustig (2016), Lustig (2018a), and Lustig (forthcoming).

${ }^{21}$ For this reason, the international convention concerning how to measure welfare proposed by the Canberra Group acknowledges the need to broaden the conceptual definition of household income to add benefits in kind such as publicly provided education and healthcare services. See, for example, (United Nations Economic Commission for Europe, 2011).
} 
national level; a detailed description of the characteristics of each tax and spending item to be included in the analysis: and, audited or confirmed budget and administrative data for the survey year.

If the fiscal incidence analysis is to take into account the indirect effect of certain taxes or subsidies that are used as key inputs in the production of final goods (for example, duties on oil imports; or, fuel, electricity, and transportation subsidies), one would also need either a recent input-output table, a Social Accounting Matrix (SAM), or a Supply and Use Table (SUT). The incidence of indirect taxes (subsidies) with or without these indirect effects can be significantly different especially if the taxed (or subsidized) product is a pervasive input in production. When such is the case (as with electricity or fuel), consumable income calculated with the indirect effects can be quite different than if such effects are assumed away.

Although the process of calculating the core income concepts seems utterly simple, in practice it is very complex even in the basic accounting approach. There are data challenges and conceptual challenges. First, especially in low-income countries, the data is frequently absent, incomplete, and/or quite difficult to obtain. Although advanced countries (and most middle-income countries) collect household surveys periodically, that is not the case in low-income countries. ${ }^{22} \mathrm{~A}$ second problem is that, with exceptions, household surveys collect data on either income or consumption. ${ }^{23}$ Lack of data on consumption patterns, implies that the incidence of consumption taxes and subsidies cannot be calculated, unless one resorts to "borrow" information on consumption patterns from a similar country and/or use econometric techniques to predict consumption based on income. Even if surveys exist, in many countries governments still restrict the access to the microdata, a factor that limits the ability of independent researchers to carry an analysis of their own. Data limitations, moreover, affect not only the microdata. Especially (but not only) in low-income countries, total taxes collected by federal, state, and local governments and actual spending on education by level, for instance, may be impossible to obtain.

In addition, the empirical analysis is made more complicated because of inconsistencies between information obtained from microdata such as household surveys and that found in macrodata such as government budgets, administrative registries (e.g., tax returns), and National Accounts. Two typical problems that arise are, for example, that the number of beneficiaries of a particular welfare program according to the household survey may differ substantially from the number recorded in administratitive registries. A second and serious limitation of household survey data is the

\footnotetext{
22 According to Lustig (forthcoming): "The data in the World Bank's PovcalNet presently cover 153 countries of which 34, as of July 2013, are classified as High Income (Atkinson, 2016). However, lack of data is still a problem. In the Middle East and North Africa (MENA) region, where there are 19 countries, only around half are covered by PovcalNet. Furthermore, according to World Bank (2016) the largest possible set of countries on which at least two comparable data points are available between the years of 2008 and 2013 was 83 countries. This set covered $75 \%$ of the world's population but fewer than half of the world's countries; population coverage was 94\% in the East Asia and Pacific region but only $23 \%$ in Sub-Saharan Africa."

23 A common practice in the absence of income data in household surveys is to assume that total consumption is equal to total disposable income and work backwards to generate the concept of market income by subtracting transfers and adding taxes. For details, see Higgins and Lustig (2018).
} 
undercoverage and underreporting of top incomes. ${ }^{24}$ In part (but not only) due to the "missing rich" problem, for most countries in the world, totals for household income and consumption from surveys do not match the equivalent totals from National Accounts. ${ }^{25}$ To make matters worse, frequently discrepancies are not limited to levels of different types of household economic resources but extend to their changes over time. ${ }^{26}$

Given these discrepancies between survey-based income and consumption data and National Accounts, which totals should one use in fiscal incidence analysis? Both approaches have been followed in the literature. Fiscal incidence exercises in WID.World, for example, scale up survey totals to match National Accounts (and tax records and budgetary data) and produce Distributional National Accounts (DINA). ${ }^{27}$ However, scaling-up is not done mechanically (e.g., raising all incomes by the same proportion) but takes into account the fact that there is much more income missing at the top of the distribution, and researchers apply a combination of parametric and nonparametric methods to correct for the "missing rich." 28

At the other end of the spectrum, the fiscal incidence exercises in the CEQ Institute Data Center on Fiscal Redistribution use the scale of the economy observed in the household surveys and scale-down administrative totals to keep proportions similar to those observed in National Accounts (for example, the totals for the various fiscal components are scaled-down so that their ratio to consumption or disposable income-where the latter is obtained from the survey--is to the equivalent ratio in administrative data). ${ }^{29}$ Why would one prefer to scale variables down to the size of the economy found in household surveys? Primarily, because this is the data used in the calculation of income (consumption) poverty in all the most widely use databases on poverty. With upwardly adjusted data (and unless all the adjustment takes place at the top of the distribution), there would be significant differences in the poverty estimates shown in the fiscal incidence exercises and those found in the standard international databases and official statistics. However, if the goal is to show how National Account aggregates are distributed among households such as in the DINA project mentioned above, then survey totals will need to be scaled-up.

\section{Economic Incidence Versus Statutory Incidence}

Statutory incidence refers to the rate of taxation established by law and where the tax is proximately levied. For example, in statutory terms, an excise tax might be collected from consumers. However, as formally shown by Harberger (1962) many decades ago, the actual burden in welfare terms — that is, the economic incidence-- of a tax may be quite different from who mails the check to the tax authorities. In the case of an excise tax, the economic burden may fall entirely on the consumer,

\footnotetext{
${ }^{24}$ For an overview on this matter, see, for example, Lustig (2018c).

25 As shown in Bourguignon (2015), these differences can be very large.

${ }^{26}$ Deaton (2005).

${ }^{27}$ For details, see Alvaredo and others (2017).

28 These details are discussed in Alvaredo and others (2017) and summarized in Lustig (2018c).

${ }^{29}$ For details, see Higgins and Lustig (2018).
} 
entirely on the producer, or on both, depending on demand (or supply) elasticities. ${ }^{30}$ In partial equilibrium analysis (and in competitive economies where markets clear), if demand is completely inelastic (or supply perfectly elastic), consumers will bear the entire burden of an excise tax: the price of the good at the cash register will increase exactly in the amount of the tax. If, on the other hand, demand is perfectly elastic (or supply completely inelastic), producers will: the prices on the shelf will not change but the price that producers receive will be reduced exactly in the amount of the tax. Beyond these two limiting cases, the fundamental principle is that taxes tend to be borne by the more inelastic consumers (or, more generally, demanders) or producers (or, more generally, suppliers). In the case of payroll taxes, for instance, the more inelastic labor supply versus labor demand is, the more is the employer able to transfer the burden of employer's payroll taxes to workers in the form of lower wages: i.e., the burden is shifted backward to workers. Likewise, the burden of a tax on inputs (such as a gasoline tax on retailers) will be borne by the consumer in the form of higher prices the more inelastic his/her demand for the taxed good is vis-à-vis the supply elasticity.

In sum, the economic incidence depends on the elasticity of demand and/or supply of a factor or a good: the burden of taxes is borne by those who cannot easily adjust to the change in price induced by the tax. The economic incidence of taxes will also be affected by how revenues are used. In a general equilibrium analysis (which is necessary when taxes impact large parts of the economy), the economic incidence is also sensitive to a large number of elasticities. In open economies, the extent of factor mobility will affect on whom the burden of taxes fall. Finally, in a dynamic context, the long run economic incidence will ultimately depend on how taxes affect capital accumulation and marginal productivities of factors of production.

As mentioned in the introduction, the accounting approach (that is, studies based on the judgmental allocation of tax burdens across the income distribution) can be thought off as implicitly assuming i) completely inelastic demand functions so that the economic incidence of taxes on goods and services falls entirely on consumers: that is, the tax burden is shifted forward to consumers in full in the form of higher prices; and, ii) completely inelastic labor supply functions so that payroll taxes are fully shifted backward to workers in the form of lower wages.

In addition, the actual incidence of taxes may differ from the statutory incidence because of tax avoidance and tax evasion. Especially in developing countries, a significant portion of economic activity may take place outside of the formal market (e.g., salaried workers, self-employed, or property owners who do not pay direct taxes or contributions to social security due to the state's inability to enforce the law) or outside the market altogether (e.g., own production of consumption goods such as small farmers or peasants cultivating corn, wheat, or other staples to feed their families). Due to limited state capacity or corruption, tax collection and the distribution of benefits (whether in cash or in-kind) may operate very differently from the letter of the law.

\footnotetext{
${ }^{30}$ For an analysis of the economic incidence of taxes, see, for example, Atkinson and Stiglitz (2015), Chetty, Looney and Kroft (2009), Kotlikoff and Summers (1987) and Salanie (2011).
} 
In the case of transfers, the actual incidence can differ from the statutory rules because beneficiaries may choose to work less (thus, incomes after the transfer may not be equal to previous earnings plus the transfer) or of imperfect take up of welfare programs. In the accounting framework it is assumed that individuals do not change their labor market behavior as a result of receiving a government transfer.

As indicated above, in spite of its limitations, the accounting approach is considered a reasonable firstorder approximation and it is the most frequently used in practice. For example, when evaluating tax reform proposals, the United States Congressional Budget Office assumes that the personal income tax is fully borne by households, payroll taxes are fully borne by workers (both, the employer and employee's share), excise taxes are fully borne by buyers and corporate income tax is fully borne by the owners of capital (Salanie, 2011).

\section{Robustness Checks and Validation}

The information on direct and indirect taxes, transfers (in cash and in-kind), and subsidies, however, is often not collected in household surveys or they are collected with error. To cope with the lack of information or its inaccuracy, researchers have proposed a number of methods that rely on statistical inference, data from external sources, and common sense. ${ }^{31}$ Because the process of allocating taxes and transfers relies on assumptions (judgment calls) that one cannot truly test using standard statistical testing methods, it is recommended to carry out robustness checks to assess the sensitivity of results. For example, one may want to change assumptions on tax evasion, informality, the size of the nonmarket economy, and/or program take-up rates. Each fiscal incidence exercise needs to be subject to thorough micro and macro validation processes. ${ }^{32}$ Whenever it is not possible to determine whether one source of information is more credible than another (e.g., there is a discrepancy in number of beneficiaries of a program between surveys and administrative registries but there is no way to tell which one is accurate), the fiscal incidence exercise should be carried out for both to obtain a range rather than produce a single number.

\section{Old-Age Contributory Pensions: Deferred Income or Government Transfer?}

Among the salient conceptual challenges is whether social insurance contributory pensions should be considered as deferred or replacement income (and, thus, counted as part of prefiscal income) or a government transfer. In the incidence analysis literature, one can find both approaches: in some cases contributory pensions are considered deferred or replacement income ${ }^{33}$ while in others--especially in systems with a large subsidized component--they are considered a pure government transfer. ${ }^{34}$ In the former case, contributions during active years are treated as a form of mandatory saving and, thus,

${ }^{31}$ For details, see Higgins and Lustig (2018).

32 See, for example, the recommendations in EUROMOD (2017), pp. 20-22.

33 Alvaredo and others (2015); Breceda, Rigolini and Saavedra (2008); Immervoll and others (2009).

34 Goñi, López, and Servén (2011); Immervol and others (2009); Lindert, Skoufias and Shapiro (2006); Silveira and others (2011). 
subtracted from the prefiscal income concept to avoid double counting and the income from pensions are treated as part of prefiscal income: that is added to earnings, income from capital, and private transfers. When pensions are considered a government transfer, contributions are treated as any other direct tax and the income from pensions is added to other government transfers to obtain total transfers. See Figure 1.

The true situation, however, is likely to be in between the two cases for many individuals. Since contributions to the system during working years can count as "mandatory saving," whether an individual receives a transfer depends on the size of the replacement income and her life expectancy. However, to identify how much is a pure transfer (or tax) and how much is replacement income with cross-section household surveys is very difficult.

Although the question whether a particular benefit is deferred income or a transfer also pertains to other components of public spending such as contributory health spending, disability benefits, and unemployment compensation, the assumption made about pensions significantly affects the order of magnitude of fiscal redistribution, especially in countries with a high proportion of retirees and generous contributory pensions. In Figure 2, one can observe that the redistributive effect with pensions as transfers is much higher (double or triple in some cases) for the European Union, Russia, Armenia, the United States, Uruguay, and Argentina, for example. Why? In populations with a large proportion of retirees, if pensions are treated as a government transfer prefiscal or market income will be zero or close to zero for a large number of individuals. The fiscally-induced inequality and poverty reduction then will be very large because the system will feature many of what one could call "false poor." 35

\footnotetext{
35 Some may argue that, in the absence of a government-sponsored program, individuals would not save enough for their old-age and could become much poorer so treating pensions as a transfer makes sense. However, the government's role could be just that of a "piggy bank" 35 forcing individuals to save during their working years to ensure an income stream during retirement. Reflecting this role, many countries place Social Security in a separate budget, protected from the politics governing other public expenditures.
} 
Figure 2: Redistributive Effect Under Pensions as Deferred Income and Pensions as Government Transfer

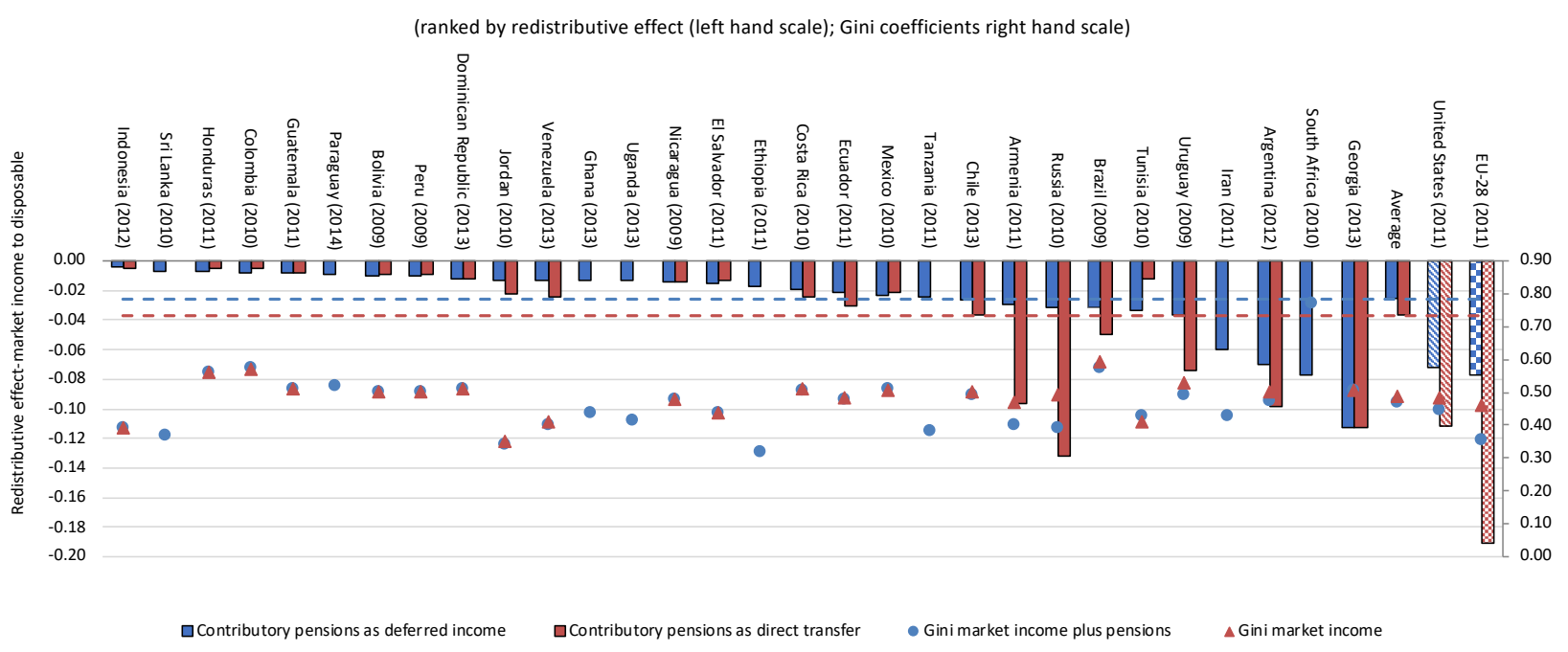

Note: the redistributive effect is calculated as the difference between the Gini coefficient for disposable income minus the Gini coefficient for market income plus pensions (pensions as deferred income scenario) or minus the Gini coefficient for market income (pensions as transfer scenario).

Source: Lustig (2018b), Figure 10-8 based on country studies in CEQ Data Center on Fiscal Redistribution http://www.commitmentoequity.org/datacenter. For EU (28 countries) own calculation based on EUROMOD version G3.0.

To make the point of the "false poor" clearer, let's assume a pensioner had been earning a high wage during her working years and that, privately, she could have saved enough so that at the time of retirement, her pension would have been at an x percent replacement ratio. Let's assume that instead she receives a pension from the social security system and that this is her only income. If her pension is treated as a pure government transfer, she will have been ranked among high wage-earners during her working years and fall to the pre-fisc destitute poor during retirement. This does not make sense.

Although any government tax or transfer might generate behavioral changes ${ }^{36}$, social security is special in the sense that it is a lifelong contract between a working individual and society. Although a CCT or other cash transfer will likely induce some behavioral changes, not having a government-sponsored retirement plan would generate major behavioral changes in a significant part of the population commanding an even larger share of income. Since in the accounting approach behavioral responses are not modelled, the alternative is to present results for both scenarios -pensions as pure deferred or

\footnotetext{
36 Bosch and Campos-Vázquez (2014); Camacho, Conover and Hoyos (2014); Garganta and Gasparini, (2015).
} 
replacement income and pensions as pure government transfer-and treat the results as a lower and upper bound of the redistributive impact of the state. ${ }^{37}$

\section{The Challenge of V aluing Transfers In-Kind}

Another conceptual challenge of importance is which method should be used for allocating benefits from public spending on government services such as education and healthcare. In the literature, three approaches have been suggested: to value these services at the production cost to the government, at the opportunity cost in the private sector, or by the households' willingness to pay. ${ }^{38}$ A basic definition utilised for the unit cost of providing a service is total government spending on a particular service divided by the number of users of that service. While this method has notable shortcomings (for example, there is no account for differences in quality of the service), it amounts to asking a valid question: How much would the income of a household have to be increased if it had to pay for the free or subsidized public service at the full cost to the government?

Moreover, if the goal is to produce distributional national accounts - that is, to take the totals in government budgets and distribute them among households--combining the information of unitary production cost with the usage of the service appears to be a sensible option. If the goal is to determine how much these services are "worth" to households, however, valuing services at production costs is not an appropriate method. Methods that estimate the willingness to pay are better suited. In sum, rather than choosing one method above others, researchers should use different methods depending on the question asked. ${ }^{39}$

\section{Limitations of Standard Fiscal Incidence Analysis}

Ideally, fiscal incidence analysis should cover all the taxes and all the components of public spending. In practice, however, it usually includes only a portion of a government's budget. ${ }^{40}$ The difficulties are particularly strong when dealing with revenue and public spending items that are not easy to "assign" to households as is the case with revenues stemming from taxing state-owned companies (quite significant in countries where natural resources are directly exploited by the state, for example) and

\footnotetext{
${ }^{37}$ It is important to note that contributory pensions can exert an equalizing effect or an unequalizing one. Lustig (2018b), for instance, shows that in Bolivia, Colombia, El Salvador, Honduras, Mexico, Nicaragua, and Tunisia, contributory pensions are unequalizing.

38 Aaron and McGuire (1970) were among the first to set out the principle that a rationed, publicly provided good (or service) should be evaluated at the individual's own valuation of the good rather than through some ad hoc assumption. On the available methods and their shortcomings see, for example, Bastagli (2015); Brennan (1976); Cornes (1995); Demery (2003); and, van de Walle (1998).

39 A variant of the production cost approach bypasses focuses only on whether a service is used or not. Lionel Demery describes it as follows: "For each service, households are assigned an "accessi-bility dummy" taking the value of unity for those that used the service, and zero for those that did not... The distribution of this dummy across income groups provides a measure of the equity of service provision." (Demery, 2003, p. 45).

${ }^{40}$ For instance, the fiscal incidence studies for thirty countries reported in the CEQ Institute's Data Center, on average, cover about 50 percent of the government revenues and spending. http://www.commitmentoequity.org/datacenter .
} 
spending on genuine public goods such as defense. ${ }^{41}$ If the excluded components are not distributional or poverty-neutral, then the full redistributive impact of the state--even within the confines of the accounting framework--may be quite different from those obtained from a fiscal incidence analysis that only partially covers taxes and transfers.

To the above, one must add the shortcomings of assuming away behavioral responses, general equilibrium effects, spillovers, and intertemporal redistribution. In some contexts, however, behavioral responses can be quite significant so results based on first-order approximation must be taken with great caution. ${ }^{42}$ For instance, a beneficiary of a means-tested transfer may decide to work less than otherwise to avoid losing his eligibility; if schools offer free lunches, parents may decide to send their children to school to take advantage of them; access to local health clinics may induce parents to be more mindful of their children's health. ${ }^{43}$

In essence, these effects can alter the counterfactual income (i.e., the income without taxes and transfers) and, thus, modify not only the size but also the sign of the estimated fiscal redistribution. An alternative to the accounting approach is to model behavioral responses in the incidence analysis. This can be done in a partial equilibrium or general equilibrium framework. ${ }^{44}$ Intertemporal effects and lifetime tax incidence can also be done as long as there is the necessary data because results depend critically on the lifetime earnings profile of household members. ${ }^{45}$

\section{Key Indicators in Fiscal Incidence Analysis}

As stated in the introduction, the typical questions that fiscal incidence analysis is meant to address include: Who bears the burden of taxation and who receives the benefits of public spending? How much income redistribution? What is the impact of taxation and public spending on poverty and the poor? How equalizing are specific taxes and components of public spending? How progressive are spending on education and health? How effective are taxes and government spending in reducing inequality and poverty? Who are the losers and winners of tax and welfare programs reforms? Here I shall discuss the indicators for the first four. The effectiveness indicators are discussed in detail in Enami (2018) and Lustig and Higgins (2018).

\footnotetext{
41 The Distributional National Accounts (DINA) in the database WID. World of the Paris School of Economics apportions all components of the government budgets assuming that the benefits from public spending on pure public goods such as defense and infrastructure spending are proportional to the prefiscal distribution of income.

42 Ravallion and Chen (2015).

43 Bourguignon and Pereira da Silva (2003).

${ }^{44}$ For partial equilibrium analysis, see, for example, Coady (2006); Harberger (1962); Gertler and Glewwe (1990); Gertler and van der Gaag (1990); McClure (1970); Mieszkowsky (1967); Musgrave (1959); Rolph (1954); van de Walle (1998 and 2003); and, Younger and others (1999). An example of fiscal incidence analysis in general equilibrium framework is the article by Devarajan and Hossein (1998) for the Philippines. For estimates of the spillover effects of cash transfer programs, see Barrientos and Sabates-Wheeler (2009); Angelucci and De Giorgi (2009). There are other spillover effects through the externalities that a better educated and healthier population generates on society as a whole.

45 See, for example, the fiscal incidence analysis in an intertemporal setting for the United States by Fullerton and Rogers (1991) and Slemrod (1992).
} 
Regarding assessing the winners and losers of fiscal reforms, all the nonanonymous indicators described below are useful to assess this. As a reminder to readers, some of the key indicators are anonymous while others are nonanonymous. Anonymous indicators are those which rank individuals (using household per capita or equivalized income) by the variable of interest (that is, by market income, disposable income, consumable income, and final income). Nonanonymous indicators are calculated with individuals ranked by the prefiscal income, and this ranking is kept fixed throughout the incidence analysis. The latter can be viewed as indicators of "fiscal mobility" induced by the combined effect of taxes and transfers where mobility does not refer to changes over time but to "before-after" (fiscal policy) situations.

Also, it is important to note that all the indicators discussed in this section can be calculated for any type of fiscal incidence exercises, and not just for the accounting approach. As long as one can generate results at the household level (or, if not at the household level, at least for grouped data by fractiles or bins), the indicators can be calculated for the more elaborate fiscal incidence analyses that include behavioral responses, and general equilibrium and intertemporal effects.

Finally, although the typical fiscal incidence exercise focuses primarily on the impact on the personal distribution of income, one may also be interested in how taxes and transfers affect the welfare of different morally or institutionally relevant social groups such as groups of individuals differentiated by gender, ethnicity, or location. In the literature, there are examples of fiscal incidence analysis by the sociodemographic categories. ${ }^{46}$ Fiscal incidence analysis by gender is one of the most challenging. ${ }^{47}$

Who Bears the Burden of Taxation and Who Receives the Benefits of Public Spending?

The most common indicator used in fiscal incidence analysis since its inception consists in presenting the information of taxes paid and benefits received by decile, quintile, or income categories. This is a nonanonymous indicator. That is, households are ranked by prefiscal income. A typical fiscal incidence table looks as Table 1 which shows results for Brazil by prefiscal income decile and the grand total at the bottom:

\section{Table 1: Fiscal Incidence by Component: Brazil (2009)}

Panel A: Absolute Incidence (in reais)

\footnotetext{
${ }^{46}$ For an analysis by urban-rural population see, for example, Cabrera, Lustig and Moran (2015). For an analysis by ethnicity and race see, for example, Lustig (2017). For fiscal incidence analysis by gender see the Further Readings section in this article.

${ }^{47}$ See Greenspun and Lustig (2018).
} 


\begin{tabular}{|cccccrr|r|}
\hline & $\begin{array}{c}\text { Distribution of prefiscal } \\
\text { income }\end{array}$ & Taxes & Transfers & Education & Health \\
\hline & & & & & \\
\hline 1 & $13,081,969,567$ & -2948373988 & $10,421,337,948$ & $25,140,139,803$ & $8,962,060,295$ \\
2 & $29,813,431,543$ & -5229994493 & $8,481,237,822$ & $22,385,815,538$ & $9,468,199,385$ \\
3 & $45,844,250,445$ & -7711304871 & $7,229,517,809$ & $21,631,928,109$ & $10,045,337,871$ \\
4 & $62,865,228,643$ & -10746049330 & $6,980,073,476$ & $21,065,715,763$ & $10,217,543,692$ \\
5 & $82,855,122,780$ & -14532187216 & $8,220,231,177$ & $19,175,597,836$ & $9,968,867,505$ \\
6 & $107,627,764,805$ & -19095182907 & $7,296,601,164$ & $18,502,749,799$ & $10,017,548,391$ \\
7 & $140,405,251,414$ & -24767853744 & $7,555,971,413$ & $16,754,722,212$ & $9,407,380,882$ \\
8 & $189,900,201,546$ & -35094164551 & $8,404,069,442$ & $15,096,909,627$ & $7,739,770,634$ \\
9 & $281,694,143,183$ & -55327392595 & $8,200,982,452$ & $12,848,954,793$ & $5,175,694,597$ \\
10 & $782,007,064,983$ & -190239623650 & $16,395,055,536$ & $10,635,658,533$ & $3,004,012,636$ \\
Total & $\$ 1,736,094,428,908$ & $-\$ 365,692,127,346$ & $\$ 89,185,078,240$ & $\$ 183,238,192,014$ & $\$ 84,006,415,889$ \\
\hline
\end{tabular}

Panel B: relative incidence (each component as a \% of prefiscal income)

\begin{tabular}{|cccccc|}
\hline \multicolumn{7}{c}{$\begin{array}{c}\text { Distribution of prefiscal } \\
\text { income }\end{array}$} & Taxes & Transfers & Education & Health \\
\hline 1 & & & & & \\
\hline 2 & $13,081,969,567$ & $-23 \%$ & $80 \%$ & $192 \%$ & $69 \%$ \\
3 & $29,813,431,543$ & $-18 \%$ & $28 \%$ & $75 \%$ & $32 \%$ \\
4 & $45,844,250,445$ & $-17 \%$ & $16 \%$ & $47 \%$ & $22 \%$ \\
5 & $62,865,228,643$ & $-17 \%$ & $11 \%$ & $34 \%$ & $16 \%$ \\
6 & $82,855,122,780$ & $-18 \%$ & $10 \%$ & $23 \%$ & $12 \%$ \\
7 & $107,627,764,805$ & $-18 \%$ & $7 \%$ & $17 \%$ & $9 \%$ \\
8 & $140,405,251,414$ & $-18 \%$ & $5 \%$ & $12 \%$ & $7 \%$ \\
9 & $189,900,201,546$ & $-18 \%$ & $4 \%$ & $8 \%$ & $4 \%$ \\
Total & $\$ 281,694,143,183$ & $-20 \%$ & $3 \%$ & $5 \%$ & $2 \%$ \\
\hline
\end{tabular}

Source: Higgins, Sean and Claudiney Pereira. 2014. "The Effects of Brazil's Taxation and Social Spending on the Distribution of Household Income," in The Redistributive Impact of Taxes and Social Spending in Latin America, edited by Nora Lustig, Carola Pessino and John Scott, Special Issue, Public Finance Review 42, no. 3, pp. 346-67. DOI: 10.1177/1091142113501714

On the first column of Panel A, Table 1 shows total income before taxes and transfers. The subsequent columns show, respectively, total taxes paid, total cash transfers received and total transfers in-kind received in education and health (measured at average cost to government). Panel b shows the incidence of each fiscal intervention with respect to prefiscal income. In this table, it is easy to observe the difference between absolute and relative progressivity. Let's look at, for example, taxes. Panel a shows that taxes are progressive in absolute terms: taxes paid increase with income (since deciles have identical number of individuals, it suffices to look at the total by decile to determine this). However, in panel $\mathrm{b}$ one observes that the poorest decile pays a higher proportion of taxes $(23$ percent with 
respect to its prefiscal income) than all the other deciles except the top one. Thus, taxes are regressive in relative terms except at the top end.

Now let's look at transfers. Transfers are everywhere progressive in relative terms: the proportion of transfers received with respect to prefiscal income declines with income. However, transfers are not progressive everywhere in absolute terms. To see this, for example, note that even though the richest decile receives only 2 percent in transfers, the amount the top decile receives in absolute terms is 57 percent higher than the bottom decile's.

With this information on hand one can calculate a variety of indicators such as the ratio of each component of fiscal policy vis-à-vis prefiscal income, concentration shares (e.g., the distribution of each fiscal instrument across fractiles or income groups), and the relative share adjustment defined for each income group as the share of actual income divided by the share of income under the assumption that government taxation-cum-expenditures do not affect the distribution of income.48

The concentration shares are commonly used to illustrate who bears the burden of taxes or receives the benefit of transfers. Based on the data shown for Brazil in Table 1, for example, $52 \%$ of collected taxes are paid by the richest decile while the poorest decile pays only $0.8 \%$ of the total. Clearly, the burden of taxes falls disproportionately on the richest echelon. However, as shown in Panel b, the relative incidence of taxes is not progressive everywhere: the bottom decile pays a higher share of its prefiscal income than every other decile than the top. Hence, there is room to make the tax system more progressive by, for instance, reducing the taxes that must be paid by the poorest decile and raising them for the second richest (i.e., the ninth) decile.

\section{How Much Income Redistribution Is Being Accomplished?}

To measure the extent of income redistribution one can calculate any of the conventional inequality measures for each income concept and subtract one from the other to measure the sign and extent of redistribution. ${ }^{49}$ For example, subtracting a typical indicator such as the Gini coefficient for market from the Gini coefficient for disposable income shows how much redistribution is achieved by direct transfers and taxes (see Figure 2 above, for an example), while the analogous calculation with disposable and consumable income Gini coefficients shows how much redistribution is achieved by indirect subsidies and taxes. Comparing market and final income Gini coefficients shows how redistributive the fiscal system is when considering all the analyzed instruments at once.

By definition, all standard inequality measures are anonymous. In other words, one does not know (actually, more strongly, one does not care) whether, for example, the poorest person using the

\footnotetext{
48 See Baum (1987) and Ruggeri (2003), p. 27.

${ }^{49}$ For a description of typical inequality indicators and their properties see, for example, Atkinson and Bourguignon (2000 and 2015a), Cowell (2009), Duclos and Araar (2006), and Jenkins and van Kerm (2009). In addition to the standard measures of inequality, one can also calculate the impact of fiscal policy on inequality of opportunity measures in the sense proposed by Roemer (1998); see also Barros and others (2009) and Ferreira and Gignoux (2011).
} 
disposable income scale is the same as the poorest person using the market income scale. However, an important desirable characteristic of fiscal systems is that they do not result in arbitrary switching of individuals' positions in the income scale. That is, unless there are reasons that justify the switch, the poorest person should not jump ahead of the second poorest person according to market income because of the impact of taxes and transfers. ${ }^{50}$

In the literature, switches are called reranking and the extent to which these switches are absent is called horizontal equity. ${ }^{51}$ Reranking refers to the phenomenon when fiscal interventions arbitrarily alter the relative position of individuals (or households) across the distribution. In other words, reranking occurs if individual A was poorer than individual B before net taxes, but B is poorer than A after net taxes. The definition of horizontal equity postulates that the prefiscal policy income ranking should be preserved. In other words, if individual A was poorer than individual B in the prefiscal situation, individual A should continue to be poorer than individual B in the postfiscal one. Reranking is interpreted as a measure of fiscally-induced horizontal inequality. The more reranking there is, the more horizontal inequity. An indicator of the extent of reranking-that is, of horizontal inequity--is the Atkinson-Plotnick index. ${ }^{52}$ By definition, the latter is a nonanonymous indicator.

Reranking has also powerful implications when assessing the contribution of a specific tax or transfer or combinations of them. In particular, reranking can potentially destroy the conventional public finance dictum that: "...for a given level of tax and spending, the more revenue collection is concentrated in more redistributive taxes (progressive income taxes) and the more spending is concentrated in more redistributive transfers (well targeted social transfers), the greater the redistributive impact of fiscal policy." 53

To illustrate, let's think of a hypothetical case in which following this dictum causes extreme reranking: that is, households switch places in such a way that the prefiscal richest becomes the postfiscal poorest, the second prefiscal richest becomes the second postfiscal poorest, and so on. Under such circumstances, any anonymous inequality indicator would show that the fiscal system's impact was exactly nil. Although such an extreme situation is not likely to ever occur in real life, actual fiscal systems show quite a bit of reranking. ${ }^{54}$ Thus, in order to determine whether a particular change on a tax or a transfer is equalizing or not, one must resort to an empirical calculation since relying on the characteristics of such the tax or transfer (whether its size or progressivity) to predict the impact of changing them, can yield the wrong results.

\footnotetext{
50 "Justifiable reasons" for a swap may include, for example, that poorest person suffers a chronic illness with much higher medical expenses than the second poorest person.

51 See, for example, Duclos and Araar (2006), p. 141. Reranking, however, is one measure of horizontal inequity. The socalled classical measures of horizontal inequity focus on whether equals are treated as equals by the fiscal system. Duclos and Araar discuss both in their Chapter 8. Also see Atkinson (1980).

${ }^{52}$ For a formal definition of the Atkinson-Plotnick indicator and how to calculate it see, for example, Duclos and Araar (2006), p. 145.

53 Clements and others (2015, p.57).

54 See, for example, the country cases in Inchauste and Lustig (2017).
} 
Just as with inequality, one can assess the impact of the fiscal system by tracing out the change in poverty across income concepts ${ }^{55}$ with any of the standard poverty measures such as the headcount ratio, the poverty gap ratio, the squared poverty gap, and so on, and with international and national poverty lines. ${ }^{56} \mathrm{It}$ is advisable to carry out dominance tests to assess whether poverty is unambiguously lower in one income distribution (e.g., disposable income compared with market income) than another for a range of poverty lines and broad class of poverty measures..$^{57}$

Poverty indicators are anonymous by definition. As a result, poverty comparisons are silent about whether prefiscal poor (nonpoor) individuals were made poorer (poor) by the net effect of taxation and public spending. Even if a tax and transfer system unambiguously reduces poverty (and inequality), it has been shown that the system can make a portion of the poor poorer and some of the non-poor poor. ${ }^{58}$ To quantify this phenomenon one can use the newly developed indicator of fiscal impoverishment. ${ }^{59}$ Figure 3 presents a (hypothetical) graphic representation of fiscal impoverishment and fiscal gains to the poor.

\section{Figure 3: Fiscal Impoverishment and Fiscal Gains to the Poor}

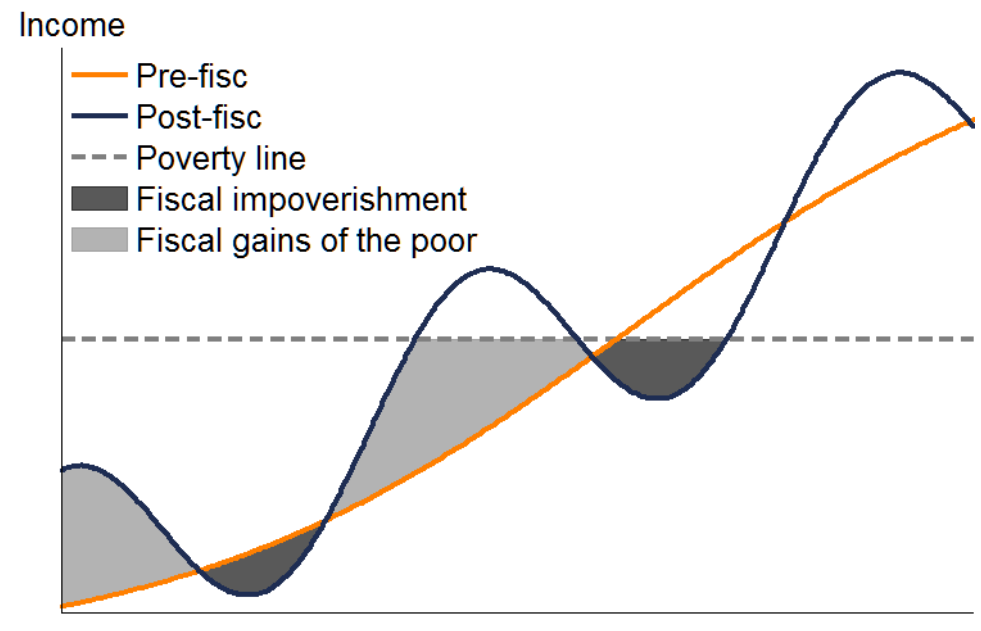

Population ordered by pre-fisc income

Source: Higgins and Lustig (2016), Figure 1.

\footnotetext{
${ }_{55}$ Because poverty lines are not calculated taking into account the access to free public services in education and health, the poverty indicators should not be calculated using the final income concept.

${ }^{56}$ For available poverty measures and their properties see, for example, Duclos and Araar (2006) and Haughton and Khandker (2009).

57 Atkinson (1987); Foster and Shorrocks, (1988).

${ }^{58}$ Higgins and Lustig (2016).

${ }^{59}$ Derived in Higgins and Lustig (2016). As shown by these authors, the fiscally-induced change in the poverty gap ratio can be exactly decomposed into the sum of fiscal impoverishment and fiscal gains to the poor.
} 
It is important to stress that fiscal systems may be equalizing but poverty increasing. ${ }^{60}$ How can that be? A simple example will help illustrate. Assume that net taxes are progressive and equalizing but that everybody is a net payer, including the poor. In such a world, fiscal policy would have reduced inequality but increased income poverty. Figure 4 illustrates how in some countries net indirect taxes increase poverty: the headcount ratio for consumable income is higher than for market income.

\section{Figure 4: Fiscal Policy and Poverty Reduction}

Panel A: contributory pensions as deferred income

(ranked by poverty reduction in \%; poverty line 1.25 dollars 2005PPP/day)

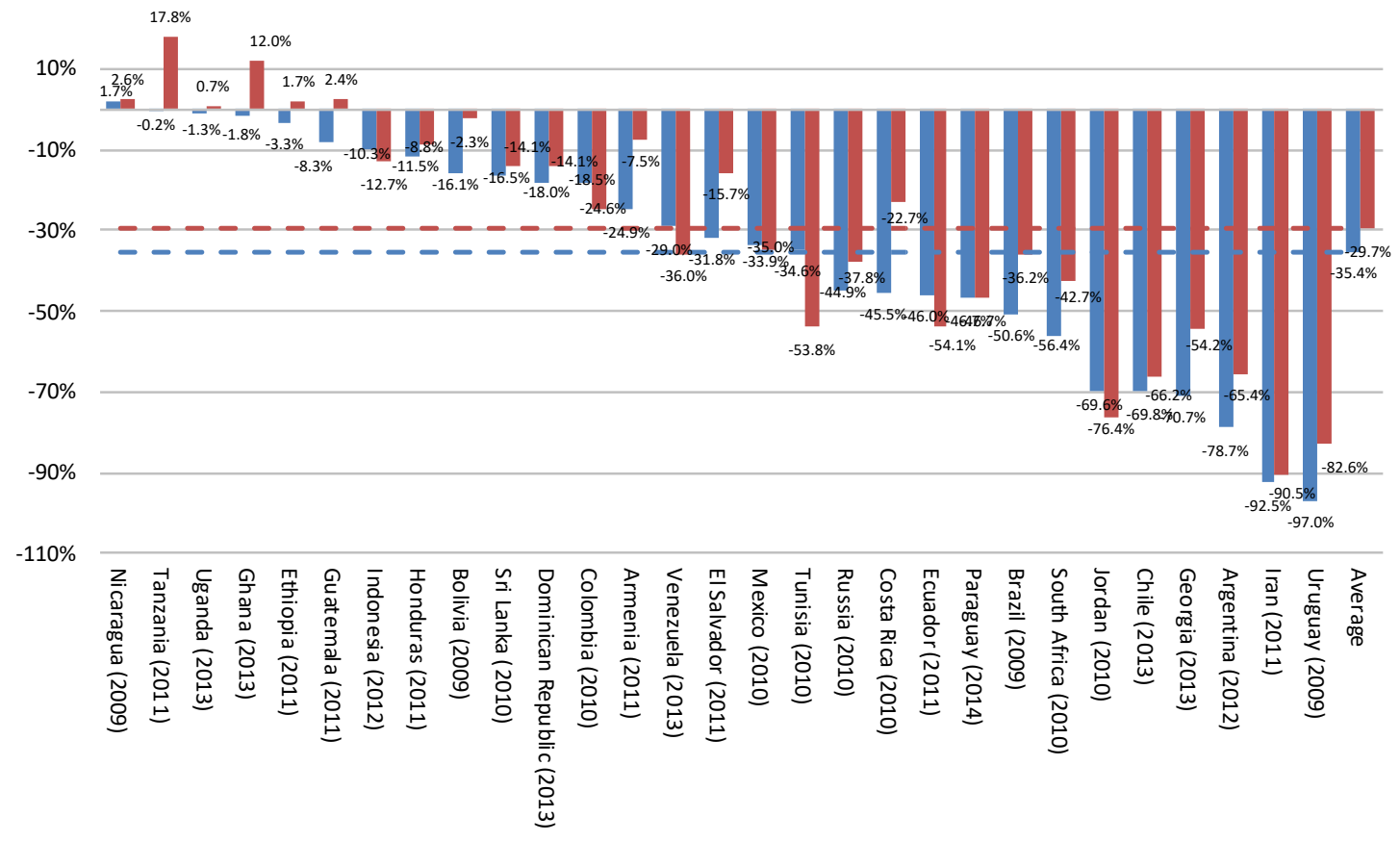

- Market income plus pensions to disposable income

Market income plus pensions to consumable income

Panel B: contributory pensions as transfers

${ }^{60}$ See Lustig (2018b) for examples of countries where this happens. 


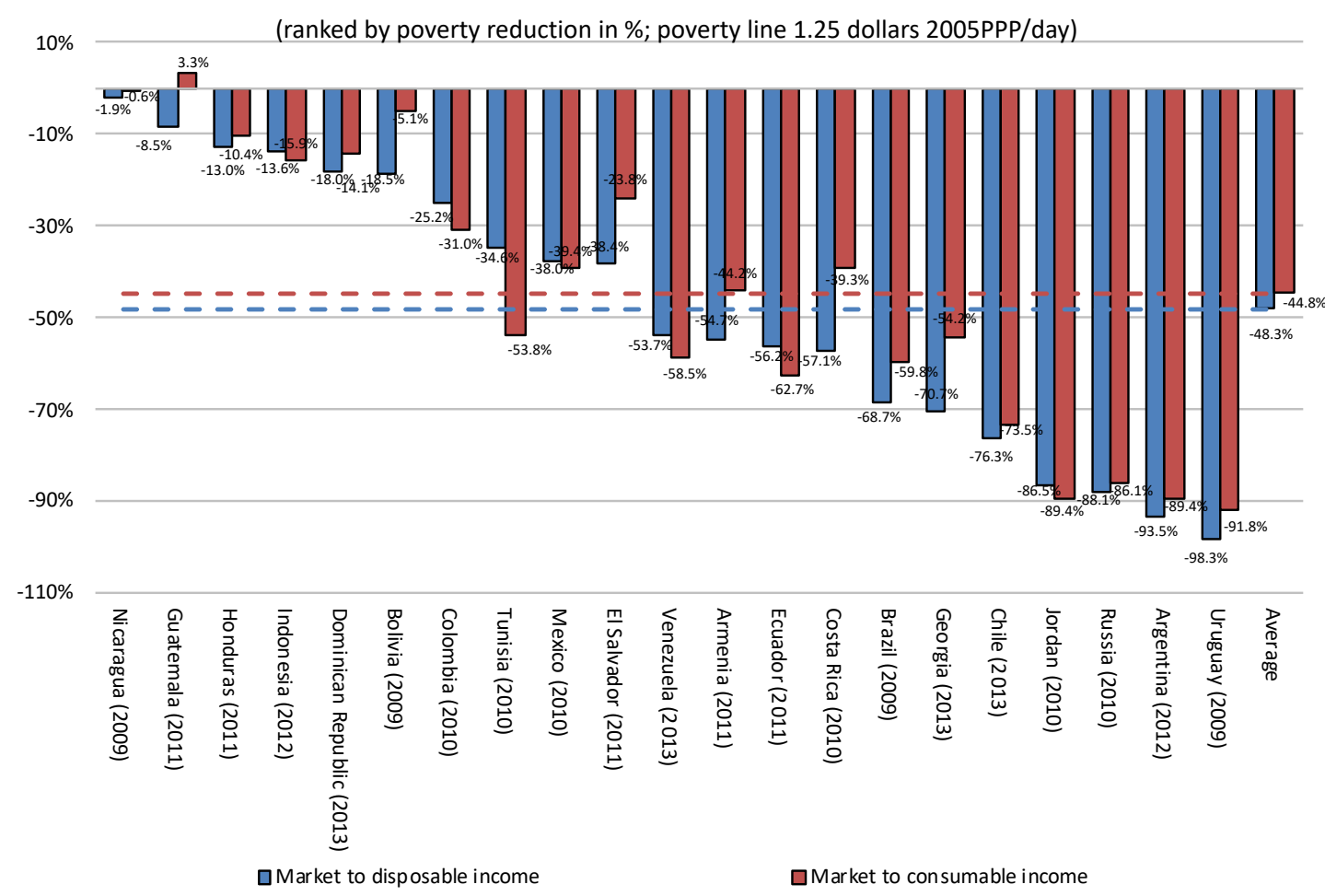

Note: The vertical axis is the percentage change of the headcount ratio for disposable income and prefiscal income (blue bar) and for consumable income and prefiscal income (red bar). The number in parenthesis is the year of the survey.

Source: Lustig (2018b), Figure 10-9.

\section{How Equalizing Are Specific Taxes and Components of Public Spending?}

A fundamental question in the policy discussion is whether a particular fiscal intervention (or a particular combination of them) is equalizing or unequalizing. Traditionally, in the incidence literature this has been measured using typical indicators of progressivity such as concentration shares or summary indicators such as the Kakwani or the Reynolds-Smolensky indexes. ${ }^{61}$

Kakwani (1977) was among the first to propose a measure of tax progressivity based on "disproportionality," that is, by the extent to which a tax distribution was not proportional to the distribution of pretax income. If the Kakwani index is positive (negative), the tax or the transfer in question is progressive (regressive). The Kakwani index for taxes is defined as the difference between the concentration coefficient of the tax and the Gini for prefiscal income. For transfers, it is defined as the difference between the Gini for market income and the concentration coefficient of the transfer. The concentration coefficient (also known as quasi-Gini) is calculated in a similar way as the Gini coefficient but it differs from the latter in that the households are always ranked by the income before

\footnotetext{
${ }^{61}$ See, for example, Kakwani (1977). For definitions of these indexes see, for example, Duclos and Araar (2006) and Enami, Lustig, and Aranda (2018).
} 
taxes and transfers (prefiscal income). The concentration curves show the distribution of a tax or a transfer with households ranked by prefiscal income. Figure 5 illustrates graphically in the case of transfers. Whenever the concentration curve for transfers lies above (below) the Lorenz curve of pretransfer income, the Kakwani index will be positive (negative) and, thus, the transfer is progressive (regressive).

The Reynolds-Smolensky index is defined as the difference between the Gini coefficient of prefiscal income and the concentration coefficient of the postfiscal income (income after a particular tax or transfer or all taxes and transfers combined, for example). If the difference is positive (negative), the tax or the transfer in question is progressive (regressive). Under no reranking, the Reynolds-Smolensky index is identical to the redistributive effect (RE) — that is, the change in inequality between pre-tax and post-tax income distribution measured in Gini points. ${ }^{62}$ Thus, in the absence of reranking, whenever the post-tax or post-transfer income Lorenz curve lies above (below) the prefiscal income Lorenz curve, the tax or transfer is progressive (regressive).

\section{Figure 5: Progressivity of Transfers: A Diagrammatic Representation}

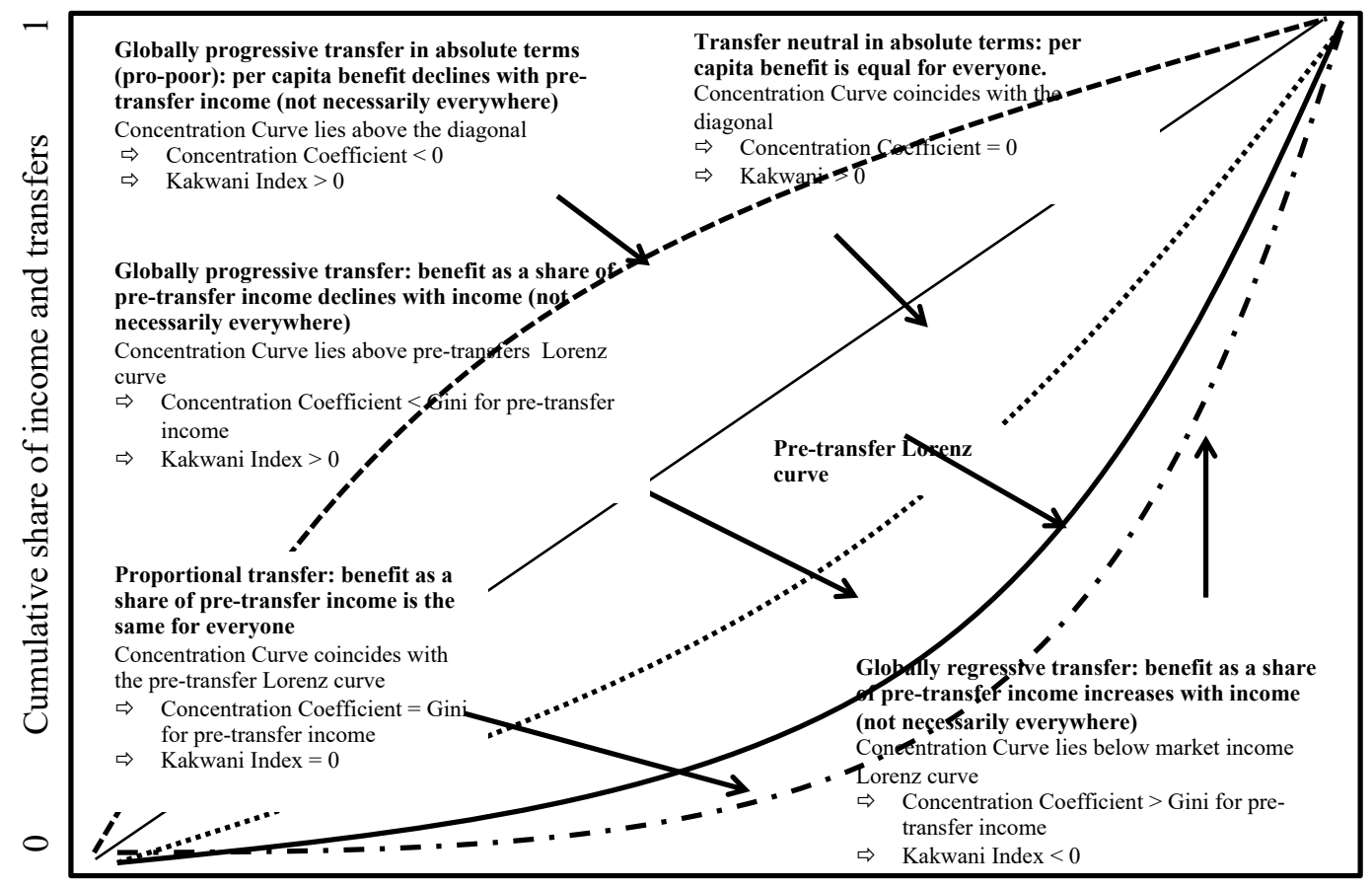

0 Cumulative share of population (ordered by market income).

\footnotetext{
${ }^{62}$ This result can be generalized to a wide range of inequality measures of the S-Gini family. See also Lambert (2001) and Duclos and Araar (2007).
} 
However, in a world with more than one fiscal intervention, it is no longer the case that a progressive (regressive) tax or transfer will be equalizing (unequalizing) by definition. In fact, it could be exactly the opposite. To my knowledge, the first author to note this counterintuitive result was Lambert (1985, 2001). Lambert shows that whether a particular tax or transfer (or any combination of them) exert an equalizing or unequalizing force depends not only on the characteristic of the fiscal instrument of interest but also on those of the rest of the fiscal system. ${ }^{63}$ Put simply, Lambert's conundrum is the consequence of path dependency: a particular tax can be regressive vis-à-vis market (prefiscal) income but progressive vis-à-vis the income that would prevail if all the other fiscal interventions were already in place. ${ }^{64}$ It is important to note that counterintuitive results can occur in the absence of reranking. If there is reranking, then one cannot be sure what the effect will be even in the case of a single fiscal instrument. ${ }^{65}$

To illustrate the point made by Lambert, let's look again at the example for Brazil in Table 1. Taxes are not progressive. In fact, the poorest decile pays (relatively) more in taxes than everybody else except the richest decile. However, if one calculates the incidence of taxes with respect to prefiscal income PLUS transfers, the tax system becomes globally progressive. That is, the (relative) incidence increases (or remains the same) as income from 13\% for the bottom decile to $24 \%$ for the richest one.

How should one calculate the contribution (i.e., the sign and order of magnitude) of a specific tax or transfer on the redistributive effect (i.e., the difference between inequality indicators for selected income concepts)? In the literature, one often encounters that the contribution is calculated sequentially. That is, as the difference between inequality indicators with fiscal interventions ordered in a path according to their institutional design. ${ }^{66}$ For example, if direct transfers are subject to taxation, the sequential contribution of personal income taxes is the difference between market income plus transfers and market income plus transfers and minus personal income taxes. Given path dependency, however, the result (in particular, the sign of the contribution) obtained by the sequential method can be wrong. It is important to note that the path dependency of fiscal interventions is independent of whether we can identify the institutional path accurately. For example, whether direct transfers are subject to taxation or not, the contribution of direct taxes to the redistributive effect can be equalizing or unequalizing (this is precisely the implication of Lambert's conundrum).

A sensible alternative is to use what in the statistical literature is known as the marginal contribution. In the context of fiscal incidence analysis, the marginal contribution of a tax (or transfer) is calculated by taking the difference between the inequality indicator without the tax (or transfer) and with it. ${ }^{67}$ For

\footnotetext{
63 See Lambert (2001, p. 277-278). Also, for a derivation of all the mathematical conditions that can be used to determine when adding a regressive tax is equalizing or when adding a progressive transfer is unequalizing, see Enami, Lustig, and Aranda (Chapter 2 in this Handbook).

${ }^{64}$ See the discussion on path dependency in chapter 7 of Duclos and Araar (2006, p. 387-406).

65 For the effects of reranking, see Enami (2018).

66. OECD (2011) used this method, for example.

67. The marginal contribution should not be confused with the marginal incidence, the latter being the incidence of a small change in spending. The marginal contribution is not a derivative. Note that, because of path dependency, adding up the marginal contributions of each intervention will not be equal to the total change in inequality. Clearly, adding up the sequential
} 
example, the marginal contribution of direct taxes is the difference between the Gini for gross income (market income plus transfers) and the Gini for disposable income (market income plus transfers minus direct taxes). If the difference is positive (negative), then direct taxes are equalizing (unequalizing). ${ }^{68}$

The marginal contribution has a straightforward policy interpretation because it is equivalent to asking the question: what would inequality be if the system did not have a particular tax (or transfer) or if a tax (or transfer) was modified? Would inequality be higher, the same or lower with the tax (or transfer) than without it? ${ }^{69}$ As an example, Figure 6 presents the marginal contributions of direct and indirect taxes, direct transfers, and indirect subsidies for a sample of countries. As can be observed, direct taxes and direct transfers are always equalizing but indirect taxes are almost neutral (very slightly equalizing) in some cases (Brazil, Chile, and Ecuador) and unequalizing in others (Georgia and Russia, in this case).

contributions will not equal the total change in inequality either. An approach that has been suggested to calculate the contribution of each intervention in a way that they add up to the total change in inequality, is to use the Shapley value. The studies analyzed here do not have estimates for the latter.

${ }^{68}$ Note that if certain fiscal interventions come in bundles (for example, a tax that only kicks in if a certain transfer is in place), the marginal contribution can be calculated for the net tax (or the net benefit) in question.

${ }^{69}$ It is important to note as well that the notion of marginal contribution is general. That is, it can be applied not only to any inequality indicator but to poverty indicators as well. The basic question is always the same: one must compare the size of the indicator without the fiscal instrument in place with the indicator that does include the latter. 


\section{Figure 6: Marginal Contributions}

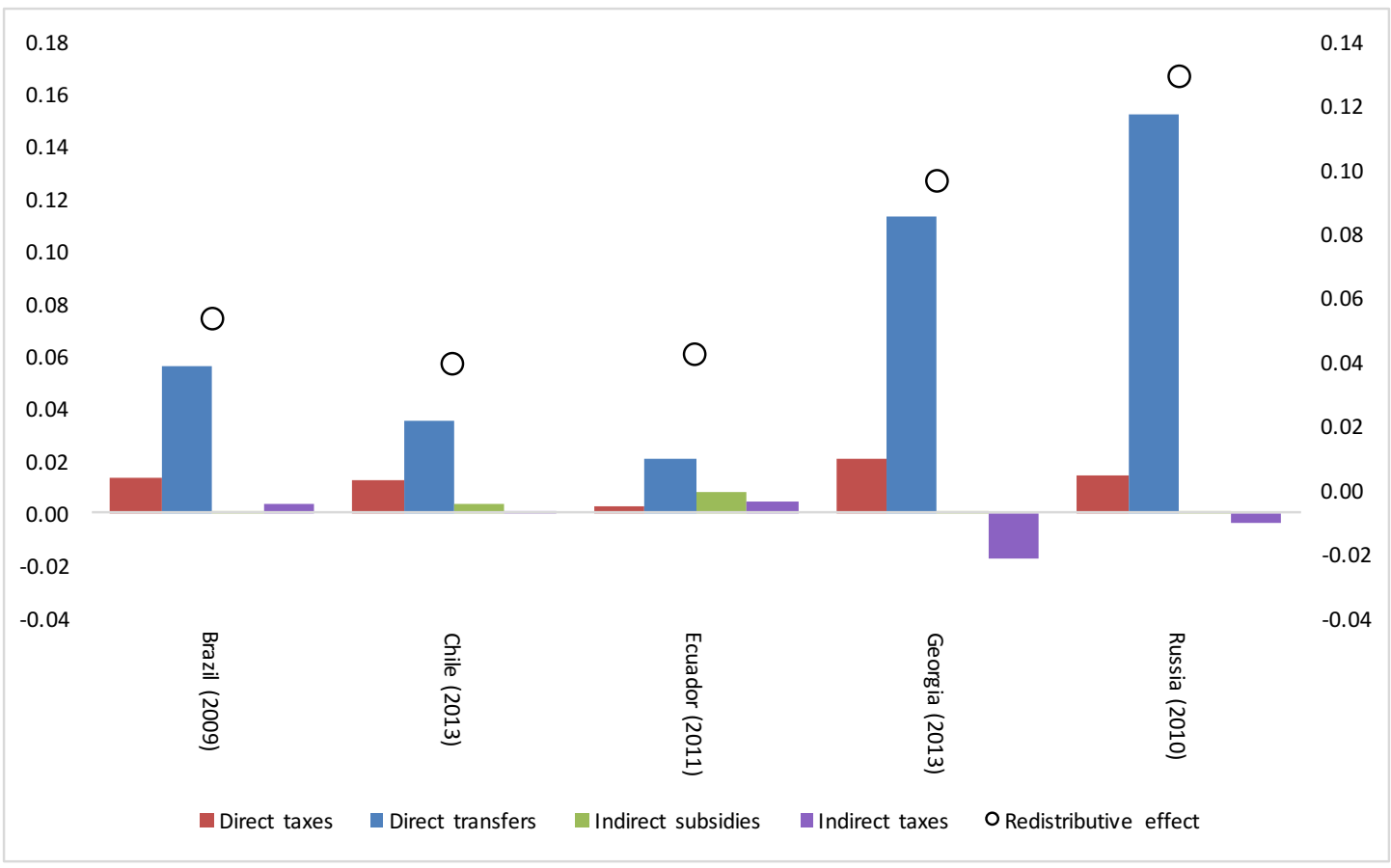

Note: The number in parenthesis is the year of the survey.

Source: CEQ Data Center on Fiscal Redistribution http://www.commitmentoequity.org/datacenter. Based on Brazil (Higgins and Pereira, 2014); Chile (Martinez-Aguilar and Ortiz-Juarez, 2018); Ecuador (Llerena and others, 2015); Georgia (Cancho and Bondarenko, 2017); Russia (Lopez-Calva and others, 2017).

The marginal contribution should not be confused with the marginal incidence, the latter being the incidence of a small change in spending. The marginal contribution is not a derivative. Note that, because of path dependency, adding up the marginal contributions of each intervention will not be equal to the total change in inequality. That is its main limitation. Path dependency would require to measure the total average contribution by considering all the possible paths. An approach that has been suggested to calculate the contribution of each intervention in a way that they add up to the total change in inequality, is to use the Shapley value (used in game theory, for instance) Interpreting the meaning of a Shapley value for policy purposes is, however, intractable. ${ }^{70}$

\section{Some Final Thoughts}

This article summarized the main conceptual components and assumptions, data requirements and indicators utilized in fiscal incidence analysis based on the accounting approach. ${ }^{71}$ One key limitation of the accounting approach is that it ignores behavioral responses as well as general equilibrium and

\footnotetext{
70. For an analysis of the Shapley value and its properties see, for example, Shorrocks (2013).

71 The reader should remember that the discussion of indicators is relevant for fiscal incidence analysis in broad terms and not just the accounting approach.
} 
dynamic effects. Among the latter, importantly, the analysis is silent regarding the effects that the fiscal system has on macroeconomic stability and economic growth. A country may appear to do quite well on the equity front by devoting a significant portion of its income to spending on safety nets for the poor and on education and health. However, if this spending is financed by distorsionary taxation, inflation, and/or unsustainable public debt, the end result may be disastrous for the poor.

A second limitation of fiscal incidence analysis as we know it, is that benefits from government services are valued at average government cost. This assumption ignores quality issues and whether consumers' valuations of the benefits actually correspond to what it costs governments to produce the services. A third limitation of fiscal incidence analysis is that households are treated as unitary: that is, the analysis assumes that taxes (benefits) paid (received) by the household are equally distributed among the members of the household. Within-household distributional issues are ignored. In spite of all its limitations, standard fiscal incidence analysis is - for the time being - the best approximation to assess the distributional impact of the current fiscal system and the potential effects of reforms.

While a summary of stylized facts is beyond the scope of this article, for an historical analysis of the progressivity of fiscal systems, the interested reader may want to consult Lindert (2004 and 2017). The references mentioned throughout this article also include numerous cases of fiscal incidence analyses for both advanced, middle-income and developing countries. Plenty of results are summarized in the data bases on fiscal redistribution housed in the CEQ Data Center on Fiscal Redistribution, EUROMOD, IDD, LIS and WID.World to name some of the leading sources. 


\section{References}

Aaron, Henry, and Martin McGuire. 1970. "Public Goods and Income Distribution." Econometrica 38: 907-18.

Abramovsky, Laura, and David Phillips. 2015. "LATAX: The Manual” Institute of Fiscal Studies. http://www.ifs.org.uk/uploads/publications/software/LATAX/LATAX\%20Manual.pdf

Adema, Willem and Maxime Ladaique. 2005. "Net Social Expenditure, 2005 Edition: More Comprehensive Measures of Social Support," Employment and Migration Working Papers 29 (OECD Social).

Alam, Shamma A., Gabriela Inchauste, and Umar Serajuddin. 2017. "The Distributional Impact of Fiscal Policy in Jordan," in The Distributional Impact of Fiscal Policy: Experience from Developing Countries, edited by Gabriela Inchauste and Nora Lustig (Washington: World Bank).

Alleyne, Dillon, James Alm, Roy Bahl, and Sally Wallace. 2004. "Tax Burden in Jamaica," Working Paper 04-34 (Georgia State University International Studies Program)

Alm, James, Fitzroy Lee, and Sally Wallace. 2005. "How Fair? Changes in Federal Income Taxation and the Distribution of Income, 1978 to 1998.” Journal of Policy Analysis and Management, Vol 24, No 1: 5-22. DOI: 10.1002/pam.20067

Alvaredo, Facundo, Anthony Atkinson, Thomas Piketty, and Emmanuel Saez, "The World Top Incomes Database," 2015 (http://topincomes.g-mond.parisschoolofeconomics.eu/).

Alvaredo, Facundo, Anthony B. Atkinson, Lucas Chancel, Thomas Piketty, Emmanuel Saez and Gabriel Zucman (2017), "Distributional National Accounts (DINA) Guidelines: Concepts and Methods used in WID.world," WID.World Working Paper, June http://wid.world/document/dinaguidelines-v1/

Angelucci, Manuela and Giacomo De Giorgi. 2009. "Indirect Effects of an Aid Program: How do Cash Transfers Affect Ineligibles' Consumption?” Working Paper 71 (International Policy Center, Gerald R. Ford School of Public Policy, University of Michigan).

Aranda, Rodrigo and Adam Ratzlaff. 2018. "Analyzing the Impact of Fiscal Policy on Ethno-Racial Inequality." Chapter 9 in Commitment to Equity Handbook. Estimating the Impact of Fiscal Policy on Inequality and Poverty, edited by Nora Lustig (Brookings Institution Press and CEQ Institute, Tulane University). Advance online version available at http://www.commitmentoequity.org/publications/handbook.php.

Aristy-Escuder, Jaime, Maynor Cabrera, Blanca Moreno-Dodson, and Miguel Sánchez-Martín. 2018. "Fiscal Policy and Redistribution in the Dominican Republic." In Commitment to Equity Handbook: Estimating the Impact of Fiscal Policy on Inequality and Poverty, edited by Nora Lustig. (Washington, DC: Brookings Institution Press and CEQ Institute). Online version available at http://www.commitmentoequity.org/publications/handbook.php

Arunatilake, Nisha, Gabriela Inchauste, and Nora Lustig. 2017. "The Incidence of Taxes and Spending in Sri Lanka," in The Distributional Impact of Fiscal Policy: Experience from Developing Countries, edited by Gabriela Inchauste and Nora Lustig (Washington: World Bank). 
Atkinson, A. 1980. "Horizontal Equity and the Distribution of the Tax Burden." In The Economics of Taxation, edited by Henry Aaron and Michael Boskin, 3-18. (Washington, DC: Brookings Institution Press).

Atkinson, Anthony B. 1983. Social Justice and Public Policy (MIT Press).

Atkinson, Anthony B. 1987. "On the Measurement of Poverty." Econometrica 55, no.4, pp. 749-764.

Atkinson, Anthony B. 2015. Inequality. What Can Be Done? (Cambridge, MA: Harvard University Press).

Atkinson, Anthony B. and François Bourguignon, editors. 2000. Handbook of Income Distribution, Vol. 1, (North-Holland, Amsterdam: Elsevier).

Atkinson, Anthony B. and François Bourguignon, editors. 2015. Handbook of Income Distribution, Vol. 2, (North-Holland, Amsterdam: Elsevier).

Atkinson, Anthony B. and Joseph E. Stiglitz. 2015. Lectures on Public Economics. (Princeton University Press).

Barr, Nicholas. 2012. "Credit Crisis and Pensions: International Scope," in: The Future of Multi-Pillar Pensions, edited by Bovenberg, Lans and van Ewijk, Casper and Westerhout (Cambridge University Press), pp. 90-141.

Barr, Nicholas. 2004. Economics of the Welfare State, 4th Edition. (New York: Oxford University Press).

Barr, Nicholas. 2001. “The Truth about Pension Reform.” Finance and Development 38, no.3, pp. 69.

Barrientos, Armando and Rachel Sabates-Wheeler. 2009. "Do Transfers Generate Local Economy Effects?” Working Paper 106 (Brooks World Poverty Institute, University of Manchester).

Barros, Ricardo, Francisco Ferreira, Jose Molinas Vegas, and Jaime Saavedra Chanduvi. 2009. Measuring Inequality of Opportunities in Latin America and the Caribbean (Washington: World Bank).

Baum, Sandra R. 1987.”On the Measurement of Tax Progressivity: Relative Share Adjustment." Public Finance Quarterly 15: 166-87.

Beckerman, Wilfred. 1979. "The Impact of Income Maintenance Payments on Poverty in Britain, 1975.” Economic Journal 89, pp. 261-279.

Beneke, Margarita, Nora Lustig, and José Andrés Oliva. 2018. "The Impact of Taxes and Social Spending on Inequality and Poverty in El Salvador.” In Commitment to Equity Handbook: Estimating the Impact of Fiscal Policy on Inequality and Poverty, edited by Nora Lustig. (Washington, DC: Brookings Institution Press and CEQ Institute). Online version available at http://www.commitmentoequity.org/publications/handbook.php

Bergh, Andreas. 2005. "On the Counterfactual Problem of Welfare State Research: How can we measure redistribution?” European Sociological Review 21, no.4.

Bibi, Sami and Jean-Yves Duclos. 2010. "A Comparison of the Poverty Impact of Transfers, Taxes and Market Income across Five OECD Countries." Bulletin of Economic Research 62, no. 4, pp. 387-406. 
Bosch, Mariano and Raymundo M. Campos-Vázquez. 2014. "The Trade-Offs of Welfare Policies," in "Labor Markets with Informal Jobs: The Case of the 'Seguro Popular' Program in Mexico," American Economic Journal: Economic Policy 6, pp. 71-99.

Bourguignon, François. 2015. The Globalization of Inequality, (New Jersey: Princeton University Press, T. Scott-Railton).

Bourguignon, François and Amadeo Spadaro. 2006. "Microsimulation as a Tool for Evaluating redistribution policies.” Journal of Economic Inequality 4, pp. 77-106.

Bourguignon, François and Luiz A. Pereira da Silva, eds. 2003. "Evaluating the Poverty and Distributional Impact of Economic Policies: A Compendium of Existing Techniques," in The Impact of Economic Poverty and Income Distribution, edited by François Bourguignon and Luiz. A. Pereira da Silva (Washington: World Bank).

Bucheli, Marisa, Nora Lustig, Maximo Rossi, and Florencia Amabile. 2014. "Social Spending, Taxes and Income Redistribution in Uruguay," in The Redistributive Impact of Taxes and Social Spending in Latin America, edited by Nora Lustig, Carola Pessino, and John Scott, special issue, Public Finance Review 42, no. 3, pp. 413-433.

Breceda, Karla, Jamele Rigolini, and Jaime Saavedra. 2008. "Latin America and the Social Contract: Patterns of Social Spending and Taxation.” Policy Research Working Paper 4604 (Washington: World Bank, World Bank Latin American and Caribbean Region Poverty Department Poverty Reduction and Economic Management Division).

Brennan, Geoffrey. 1976. “The Distributional Implications of Public Goods.” Econometrica 44: 391 99.

Browning, Edgar K., and William R. Johnson. 1979.’'The Distribution of the Tax Burden.” American Enterprise Institute, Washington, DC.

Cabrera, Maynor, Nora Lustig, and Hilcias E. Moran. 2015. "Fiscal Policy, Inequality and the Ethnic Divide in Guatemala." World Development 76 (C), pp. 263-279.

Camacho, Adriana, Emily Conover, and Alejandro Hoyos. 2014. "Effects of Colombia's Social Protection System on Workers' Choice between Formal and Informal Employment.” World Bank Economic Review 28, pp. 446-66.

Cancho, Cesar and Elena Bondarenko. 2017. "The Distributional Impact of Fiscal Policy in Georgia," in: The Distributional Impact of Fiscal Policy: Experience from Developing Countries, edited by Gabriela Inchauste and Nora Lustig (Washington: World Bank).

Chen, Shaohua and Martin Ravallion. 2010. "The Developing World is Poorer than We Thought, but No Less Successful in the Fight Against Poverty.” The Quarterly Journal of Economics 125, no.4, pp. 1577-1625.

Chetty, Raj, Looney, Adam, and Kroft, Kory. 2009. "Salience and Taxation: Theory and Evidence.” American Economic Review 99(4): 1145-77.

Clements, Benedict, Ruud Mooji, Sanjeev Gupta, and Michael Keen. 2015. "Fiscal Redistribution in Developing Countries: Overview of Policy Issues and Options," in Inequality and Fiscal Policy (International Monetary Fund), pp. 57-76.

Coady, David. 2006. "The Distributional Impacts of Indirect Tax and Public Pricing Reforms," in Analyzing the Distributional Impact of Reforms: A Practitioner's Guide to Pension, Health, 
Labor Markets, Public Sector Downsizing, Taxation, Decentralization and Macroeconomic Modeling, edited by A. Coudouel and S. Paternostro (Washington: World Bank).

Coady, David, Moataz El-Said, Robert Gillingham, Kangni Kpodar, Paulo Medas, and David Newhouse. 2006. "The Magnitude and Distribution of Fuel Subsidies: Evidence from Bolivia, Ghana, Jordan, Mali, and Sri Lanka.” International Monetary Fund Working Paper 06/247.

Colm, Gerhard, and Helen Tarasov. 1940.'Who Pays Taxes?” Study prepared for the Tem porary National Economic Committee, Monograph 3, 76th Congress, Congressional RecordAppendix Extension of Remarks 84: 3336.

Cornes, Richard. 1995. "Measuring the Distributional Impact of Public Goods." In Public Spending and the Poor: Theory and Evidence edited by Dominique van de Walle and Kimberly Nead. (Baltimore and London: Published for the World Bank by John Hopkins University Press).

Cowell, Frank A. 2009. Measuring Inequality, Series London School of Economics Perspectives in Economic Analysis, (Oxford, UK: Oxford University Press).

Davoodi, Hamid R., Erwin R. Tiongson, and Sawitree Sachjapinan. 2010, May. "Benefit Incidence of Public Education and Health Spending Worldwide: Evidence From a New Database.” Poverty \& Public Policy, 2(2): 5-52.

Deaton, Angus. 2005. "Measuring Poverty in a Growing World (or Measuring Growth in a Poor World)," The Review of Economics and Statistics 87 (1), pp. 1-19.

Demery, Lionel. 2000. “Benefit Incidence: A Practitioner's Guide.” World Bank, Poverty and Social Development Group, Africa Region, Washing-ton, D.C. Processed. Dilnot, Andrew, John Kay, and Michael Keen. 1990. "Allocating Taxes to Households: A Methodology." Oxford Working Papers 42, no.1, pp. 210-230.

Demery, Lionel. 2003. "Analyzing the Incidence of Public Spending," chapter 2 in The Impact of Economic Poverty and Income Distribution, edited by Francois Bourguignon and Luiz A. Pereira da Silva (Washington: World Bank).

Demery, Lionel, Shiyan Chao, Rene Bernier, and Kalpana Mehra. 1995. "The Incidence of Social Spending in Ghana.” PSP Discussion Paper Series 82, Poverty and Social Policy Department, World Bank, Washington, DC.

Devarajan, Shantayanan, and Shaikh I. Hossain. 1998. "The Combined Incidence of Taxes and Public Expenditures in the Philippines." World Development 26(6): 963-77.

Dilnot, Andrew, John Kay, and Michael Keen. 1990. "Allocating Taxes to Households: A Methodology," (working paper, Oxford, 42(1): 210-30).

Dodge, David A. 1975. "Impact of Tax, Transfer, and Expenditure Policies of Government on the Distribution of Personal Income in Canada." Review of Income and Wealth 21: 1-52.

Duclos, Jean-Yves, and Abdelkrim Araar, 2006. Poverty and Equity: Measurement, Policy and Estimation with DAD. Economic Studies in Inequality, Social Exclusion and Well-being 2 (New York: Springer, IDRC).

Ebrill, Liam, Michael Keen, and Victoria P. Summers. 2001. The Modern VAT. (Washington: International Monetary Fund).

Enami, Ali. 2018a. "Measuring the Redistributive Impact of Taxes and Transfers in the Presence of Reranking," Chapter 3 in Commitment to Equity Handbook. Estimating the Impact of Fiscal Policy on 
Inequality and Poverty, edited by Nora Lustig (Brookings Institution Press and CEQ Institute, Tulane University). Advance online version available at http://www.commitmentoequity.org/publications/handbook.php.

Enami, Ali. 2018b. "Measuring the Effectiveness of Taxes and Transfers in Fighting Inequality and Poverty," Chapter 5 in Commitment to Equity Handbook. Estimating the Impact of Fiscal Policy on Inequality and Poverty, edited by Nora Lustig (Brookings Institution Press and CEQ Institute, Tulane University). Advance online version available at http://www.commitmentoequity.org/publications/handbook.php.

Enami, Ali, Nora Lustig, and Rodrigo Aranda. 2018. "Analytical Foundations: Measuring the Redistributive Impact of Taxes and Transfers," Chapter 2 in Commitment to Equity Handbook. Estimating the Impact of Fiscal Policy on Inequality and Poverty, edited by Nora Lustig (Brookings Institution Press and CEQ Institute, Tulane University). Advance online version available at http://www.commitmentoequity.org/publications/handbook.php.

Engel, Eduardo, Alexander Galetovi and Claudio Raddatz. 1999. "Taxes and Income Distribution in Chile: Some Unpleasant Redistributive Arithmetic.” Journal of Development Economics 59, no. 1, pp. 155-192.

EUROMOD. 2017. “EUROMOD Modelling Conventions,” EUROMOD Technical Note EMTN 1.0, Colchester: Institute for Social and Economic Research, University of Essex.

Fellman, Johan, Markus Jäntti, and Peter J. Lambert. 1999. “Optimal Tax-Transfer Systems and Redistributive Policy.” The Scandinavian Journal of Economics: 115-126.

Ferreira, Francisco H.G. and David Robalino. 2010. "Social Protection in Latin America: Achievements and Limitations," Policy Research Working Paper 5305 (Washington: World Bank).

Ferreira, Francisco H.G. and Jérémie Gignoux. 2011. "The Measurement of Educational Inequality: Achievement and Opportunity,” Policy Research Working Paper.5873 (Washington: World Bank).

Fiszbein, Ariel, Norbert Schady, Francisco Ferreira, Margaret Grosh, Nial Kelleher, Pedro Olinto, and Emmanuel Skoufias. 2009. Conditional Cash Transfers: Reducing Present and Future Poverty (Washington: World Bank).

Förster, Michael and Peter Whiteford. 2009. "How much Redistribution do Welfare States Achieve? The Role of Cash Transfers and Household Taxes," CESifo DICE Report 7, no. 3, (Ifo Institute - Leibniz Institute for Economic Research at the University of Munich), pp. 34-41.

Foster, James and Anthony F. Shorrocks. 1988. "Poverty Orderings." Econometrica 56, no.1, pp. 173177.

Foster, James, Joel Greer, and Erik Thorbecke. 1984. "A Class of Decomposable Poverty Measures.” Econometrica 52, no.3, pp. 761-766.

Fullerton, Don and Diane Lim Rogers. 1991. "Lifetime versus Annual Perspectives on Tax Incidence." National Tax Journal 44, no.3, pp. 277-287.

Fullerton, Don and Gilbert E. Metcalf. 2002. "Tax Incidence, "Handbook of Public Economics," chap 26 in Alan J. Auerbach and Martin Feldstein, eds. Handbook of Public Economics, Volume 4, pp. 1787-1872. (New York, NY: Elsevier). 
Garganta, Santiago and Leonardo Gasparini. 2015. "The Impact of a Social Program on Labor Informality: The Case of AUH in Argentina," Journal of Development Economics 115, pp. 99-110.

Gertler, Paul, and Paul Glewwe. 1990. "The Willingness to Pay for Education in Developing Countries: Evidence from Rural Peru.” Journal of Public Economics 42 (3): 251-75.

Gertler, Paul, and Jacques van der Gaag. 1990. The Willingness to Pay for Medical Care: Evidence from Two Developing Countries. (Baltimore: Johns Hopkins University Press for the World Bank).

Gillespie, W. Irwin. "The Effect of Public Expenditures on the Distribution of Income," in Essays in Fiscal Federalism (122-86), edited by Richard A. Musgrave. (Washington, DC: Brookings Institution).

Goñi, Edwin, J. Humberto Lopez, and Luis Serven. 2011. "Fiscal Redistribution and Income Inequality in Latin America.” World Development 39, no.9, pp.1558-1569.

Greenspun, Samantha and Nora Lustig. 2018. "Gendered Fiscal Incidence Analysis. A Review of the Literature," CEQ Working Paper 76 (Commitment to Equity (CEQ) Institute, Tulane University)

Grosh, Margaret, Carlo del Ninno, Emil Tesliuc, and Azedine Ouerghi. 2008. For Protection and Promotion: The Design and Implementation of Effective Safety Nets (Washington: World Bank).

Gupta, Sanjeev, Michael Keen, Benedict Clements and Ruud de Mooij, editors. 2015. Inequality and Fiscal Policy, Washington: International Monetary Fund.

Haughton, Jonathan and Shahidur R. Khandker. 2009. Handbook on Poverty and Inequality, (Washington, DC: World Bank).

Harberger, Arnold C. 1962. “The Incidence of the Corporation Income Tax." Journal of Political Economy 70: 215-40.

Hammer, Jeffrey, Ijaz Nabi, and James A. Cercone. 1995. "Distributional Effects of Social Sector Expenditures in Malaysia, 1974 to 1989." In Public Spending and the Poor: Theory and Evidence edited by Dominique van de Walle and Kimberly Nead. (Baltimore and London: Published for the World Bank by John Hopkins University Press).

Higgins, Sean. 2018. "Producing Indicators and Results, and Completing Sections D and E of CEQ Master Workbook using the CEQ Stata Package," Chapter 8 in Commitment to Equity Handbook. Estimating the Impact of Fiscal Policy on Inequality and Poverty, edited by Nora Lustig (Brookings Institution Press and CEQ Institute, Tulane University). Advance online version available at http://www.commitmentoequity.org/publications/handbook.php.

Higgins, Sean and Nora Lustig. 2016. "Can a Poverty-Reducing and Progressive Tax and Transfer System Hurt the Poor?” Journal of Development Economics 122, pp. 63-75.

Higgins, Sean and Nora Lustig.. 2018. "Allocating Taxes and Transfers, Constructing Income Concepts, and Completing Sections A, B, and C of CEQ Master Workbook," Chapter 6 in Commitment to Equity Handbook. Estimating the Impact of Fiscal Policy on Inequality and Poverty, edited by Nora Lustig (Brookings Institution Press and 
CEQ Institute, Tulane University). Advance online version available at http://www.commitmentoequity.org/publications/handbook.php.

Higgins, Sean and Claudiney Pereira. 2014. "The Effects of Brazil's Taxation and Social Spending on the Distribution of Household Income," in The Redistributive Impact of Taxes and Social Spending in Latin America, edited by Nora Lustig, Carola Pessino, and John Scott, special issue, Public Finance Review 42, 3, pp. 346-67.

Higgins, Sean, Nora Lustig, Whitney Ruble, and Timothy Smeeding. 2016. "Comparing the Incidence of Taxes and Social Spending in Brazil and the United States." Review of Income and Wealth 62 (S1): S22-S46. doi:10.1111/roiw.12201.

Hill, Ruth, Gabriela Inchauste, Nora Lustig, Eyasu Tsehaye, and Tassew Woldehanna. 2017. "A Fiscal Incidence Analysis for Ethiopia," in The Distributional Impact of Fiscal Policy: Experience from Developing Countries, edited by Gabriela Inchauste and Nora Lustig (Washington: World Bank).

Inchauste, Gabriela and Nora Lustig, editors. 2017. The Distributional Impact of Fiscal Policy: Experience from Developing Countries. (Washington: World Bank).

Inchauste, Gabriela, Nora Lustig, Mashekwa Maboshe, Catriona Purfield, Ingrid Woolard, and Precious Zikhali. 2017. "The Distributional Impact of Fiscal Policy in South Africa," in The Distributional Impact of Fiscal Policy: Experience from Developing Countries, edited by Gabriela Inchauste and Nora Lustig. (Washington: World Bank).

Immervoll, Herwig and Linda Richardson. 2011. "Redistribution Policy and Inequality Reduction in OECD Countries: What Has Changed in Two Decades?” IZA Discussion Paper No. 6030.

Immervoll, Herwig, Horacio Levy, José Ricardo Nogueira, Cathal O’Donoghue, and Rozane Bezerra de Siqueira. 2009. "The Impact of Brazil's Tax-Benefit System on Inequality and Poverty," in Poverty, Inequality, and Policy in Latin America, edited by. Stephan Klasen, and Felicitas NowakLehmann. (MIT Press) pp. 271-302.

Jaramillo, Miguel. 2014. "The Incidence of Social Spending and Taxes in Peru," in The Redistributive Impact of Taxes and Social Spending in Latin America, edited by Nora Lustig, Carola Pessino, and John Scott, special issue, Public Finance Review 42, no.3, pp. 391-412.

Jellema, Jon, Matthew Wai-Poi, and Rythia Afkar. 2017. The Distributional Impact of Fiscal Policy in Indonesia, in The Distributional Impact of Fiscal Policy: Experience from Developing Countries, edited by Gabriela Inchauste and Nora Lustig. (Washington: World Bank).

Jellema, Jon, Astrid Haas, Nora Lustig, and Sebastian Wolf. Forthcoming. "The Impact of Taxes, Transfers, and Subsidies on Inequality and Poverty in Uganda." In Commitment to Equity Handbook: Estimating the Impact of Fiscal Policy on Inequality and Poverty, edited by Nora Lustig. (Washington, DC: Brookings Institution Press and CEQ Institute). Online version available at http://www.commitmentoequity.org/publications/handbook.php

Jouini, Nizar, Nora Lustig, Ahmed Moummi, and Abebe Shimeles. Forthcoming. "Fiscal Incidence and Poverty Reduction: Evidence from Tunisia.” In Commitment to Equity Handbook: Estimating the Impact of Fiscal Policy on Inequality and Poverty, edited by Nora Lustig. (Washington, DC: Brookings Institution Press and CEQ Institute). Online version available at http://www.commitmentoequity.org/publications/handbook.php 
Jenkins, S. P. and P. Van Kerm (2009), “The Measurement of Economic Inequality,” in The Oxford Handbook of Economic Inequality, edited by Salverda, W., B. Nolan and T. M. Smeeding, (Oxford, UK: Oxford University Press).

Kakwani, Nanak C. 1977. "Measurement of Tax Progressivity: An International Comparison." Economic Journal 87, no. 345, pp. 71-80.

Keen, Michael and Ben Lockwood. 2010. “The Value Added Tax: Its Causes and Consequences.” Journal of Development Economics 92, pp. 138-151.

Kotlikoff, Laurence J. and Lawrence H. Summers. 1987. “Tax Incidence.” Chapter 16 in Handbook of Public Economics, Volume 2, edited by Alan J. Auerbach and Martin Feldstein. (Elsevier)

Lambert, Peter. 1985. "On the Redistributive Effect of Taxes and Benefits." Scottish Journal of Political Economy 32, no.1, pp. 39-54.

Lambert, Peter. 2001. The Distribution and Redistribution of Income, 3rd edition. (Manchester University Press).

Lanjouw, Peter, and Martin Ravallion. 1999. "Benefit Incidence, Public Spending Reforms, and the Timing of Program Capture.” World Bank Economic Review 13(May): 257-73.

Lindert, Peter H. 1994. “The Rise of Social Spending, 1880-1930," Explorations in Economic History, 31, no. 1 (Elsevier) pp 1-37.

Lindert, Peter H. 2004. Growing Public. Social Spending and Economic Growth since the Eighteenth Century. Volumes I and II. (Cambridge, U.K.: Cambridge University Press).

Lindert, Peter H. 2017. “The Rise and Future of Progressive Redistribution,” CEQ Working Paper 73 (Tulane University), October.

Lindert, Kathy, Emmanuel Skoufias, and Joseph Shapiro. 2006. "Redistributing Income to the Poor and Rich: Public Transfers in Latin America and the Caribbean." Social Protection Discussion Paper 0605 (Washington: World Bank).

Llerena Pinto, Freddy Paul, Maria Cristhina Llerena Pinto, Roberto Carlos Saa Daza and Maria Andrea Llerena Pinto. 2015. "Social Spending, Taxes and Income Redistribution in Ecuador," CEQ Working Paper 28 (Center for Inter-American Policy and Research and Department of Economics, Tulane University and Inter-American Dialogue), February.

Lopez-Calva, Luis Felipe, Nora Lustig, Mikhail Matytsin, and Daria Popova. 2017. "Who Benefits from Fiscal Redistribution in Russia?," in The Distributional Impact of Fiscal Policy: Experience from Developing Countries, edited by Gabriela Inchauste and Nora Lustig. (Washington: World Bank)

Lustig, Nora. 2015. "The Redistributive Impact of Government Spending on Education and Health: Evidence from 13 Developing Countries in the Commitment to Equity Project," in Inequality and Fiscal Policy, edited by Sanjeev Gupta, Michael Keen, Benedict J. Clements and Ruud A. de Mooij (Washington: International Monetary Fund).

Lustig, Nora. 2016.. "Inequality and Fiscal Redistribution in Middle Income Countries: Brazil, Chile, Colombia, Indonesia, Mexico, Peru and South Africa." Journal of Globalization and Development 7 (1): 17-60. doi:10.1515/jgd-2016-0015

Lustig, Nora. 2017.. "Fiscal Redistribution and Ethno-racial Inequality in Bolivia, Brazil and Guatemala," Latin American Research Review. Special Issue: Enduring and/or New Forms of Inequality in a Globalizing World, Philip Oxhorn and José R. Jouve-Martin, editors, 52(2): X. 
Lustig, Nora, editor. 2018a. Commitment to Equity Handbook. Estimating the Impact of Fiscal Policy on Inequality and Poverty. (Washington, DC: Brookings Institution Press and CEQ Institute).

Lustig, Nora. 2018b. "Fiscal Policy, Income Redistribution and Poverty Reduction in Low and Middle Income Countries," in Commitment to Equity Handbook. Estimating the Impact of Fiscal Policy on Inequality and Poverty, edited by Nora Lustig. (Washington, DC: Brookings Institution Press and CEQ Institute).

Lustig, Nora. 2018c. "The Missing Rich in Household Surveys: Causes and Correction Methods," CEQ Working Paper 75 (Commitment to Equity (CEQ) Institute, Tulane University).

Lustig, Nora. Forthcoming. "Measuring the distribution of household income, consumption and wealth: state of play and measurement challenges," chapter in forthcoming For Good Measure: Advancing Research on Well-Being Metrics Beyond GDP, edited by Martine Durand, Jean-Paul Fitoussi, and Joseph E. Stiglitz, OECD report by the High Level Expert Group on Measuring Economic Performance and Social Progress.

Lustig, Nora, Carola Pessino, and John Scott, editors. 2014. The Redistributive Impact of Taxes and Social Spending in Latin America, Special Issue. Public Finance Review 42, no 3.

Martinez-Vazquez, Jorge. 2008. "The Impact of Budgets on the Poor: Tax and Expenditure Benefit Incidence Analysis.” In Public Finance for Poverty Reduction: Concepts and Case Studies from Africa and Latin America, edited by Blanca Moreno-Dodson and Quentin Wodon, 113-62. (Directions in Development Series. Washington, DC: World Bank).

Martínez, Sandra, Alan Fuchs, Eduardo Ortiz-Juarez, and Giselle del Carmen. 2018. "The Impact of Fiscal Policy on Inequality and Poverty in Chile.” In Commitment to Equity Handbook: Estimating the Impact of Fiscal Policy on Inequality and Poverty, edited by Nora Lustig. (Washington, DC: Brookings Institution Press and CEQ Institute). Online version available at http://www.commitmentoequity.org/publications/handbook.php

McClure, Charles E. 1970. “Tax Incidence, Macroeconomic Policy, and Absolute Prices." Quarterly Journal of Economics 84: 254-67.

McClure, Charles E. 1972. "The Theory of Expenditure Incidence." Finanzarchiv 30: 432-53.

McIntyre, Di and John E. Ataguba. 2011. "How to do (or not to do)... benefit incidence analysis." Health Policy and Planning, 26: 174-182.

Meerman, Jacob. 1979. Public Expenditure in Malaysia: Who Benefits and Why. (New York: Oxford University Press for the World Bank).

Melguizo, Angel, and José M. Gonzalez-Paramo. 2013. "Who Bears the Social Security Taxes? A MetaAnalysis Approach.” SERIEs - Journal of the Spanish Economic Association 4 n.3, pp. 247-271.

Mieszkowski, Peter. 1967. "On the Theory of Tax Incidence," Journal of Political Economy, LXXV, June: 250-62.

Moreno-Dodson, Blanca and Quentin Wodon. 2008. Public Finance for Poverty Reduction: Concepts and Case Studies from Africa and Latin America. (Washington, DC: The World Bank).

Morra Imas, Linda G. and Ray C. Rist. 2009. The Road to Results: Designing and Conducting Effective Development Evaluations. (Washington: World Bank).

Musgrave, Richard. 1959. The Theory of Public Finance. New York: McGraw-Hill. 
Musgrave, Richard, A., John J. Carroll, Lorne D. Cook, and Lenore Frane. 1951. "Distribution of Tax Payments by Income Groups: A Case Study for 1948.” National Tax Journal 4 (March 1951):153.

Musgrave, Richard, Karl Case, and Herman Leonard. 1974. "The Distribution of Fiscal Burdens and Benefits." Public Finance Quarterly 2 (3): 259-311.

Musgrave, Richard A. and Peggy B. Musgrave. 1976. Public Finance in Theory and Practice, 2nd ed. New York: McGraw-Hill.

O’Donnell, Owen, Eddy Van Doorslaer, Adam Wagstaff, and Magnus Lindelow. 2008. Analyzing Health Equity Using Household Survey Data: A Guide to Techniques and Their Implementation. (Washington: World Bank, WBI Learning Resources Series).

O’Donoghue, Cathal (ed.) 2014. Handbook of Microsimulation (Emerald Insight).

O’Donoghue, Cathal and Rozane Bezerra de Siqueira. 2009. "The Impact of Brazil's Tax-Benefit System on Inequality and Poverty," in: Poverty, Inequality, and Policy in Latin America, edited by. Stephan Klasen, and Felicitas Nowak-Lehmann. (MIT Press), pp. 271-302.

OECD. 2011. Divided We Stand. Why Inequality Keeps Rising (OECD Publishing).

O'Higgins, Michael and Patricia Ruggles. 1981. "The Distribution of Public Expenditures and Taxes among Households in the United Kingdom.” Review of Income and Wealth 27, no. 3, pp. 298326.

Paz Arauco, Veronica, George Gray-Molina, Wilson Jimenez, and Ernesto Yañez. 2014a. "Explaining Low Redistributive Impact in Bolivia," in The Redistributive Impact of Taxes and Social Spending in Latin America, edited by Nora Lustig, Carola Pessino, and John Scott, Special Issue, Public Finance Review 42, no 3, pp. 326-345.

Peacock, Alan T., editor. 1954. Income Redistribution and Social Policy. (London: Jonathan Cape).

Pechman, Joseph A. 1985. Who Paid the Taxes, 1966-1985. (Washingon: Brookings Institution).

Pechman, Joseph A., and Benjamin A. Okner. 1974. Who Bears the Tax Burden? (Washington DC: Brookings Institution).

Piketty, Thomas. 2014. Capital in the Twenty-First Century, (Cambridge, MA: Harvard University Press). Ravallion, Martin and Shaohua Chen. 2015. "Benefit Incidence with Incentive Effects, Measurement Errors and Latent Heterogeneity: A Case Study for China” Journal of Public Economics 128, pp. 124-132.

Reynolds, Morgan, and Eugene Smolensky. 1977. Public Expenditures, Taxes, and the Distribution of Income. (New York: Academic Press).

Roemer, John E. 1998. Equality of Opportunity. (Cambridge, MA: Harvard University Press). Rolph, Earl R. 1954. The Theory of Fiscal Economics. (Berkeley: University of California Press).

Rossignolo, Dario. 2018. “Taxes, Expenditures, Poverty, and Income Distribution in Argentina.” In Commitment to Equity Handbook: Estimating the Impact of Fiscal Policy on Inequality and Poverty, edited by Nora Lustig. (Washington, DC: Brookings Institution Press and CEQ Institute). Online version available at http://www.commitmentoequity.org/publications/handbook.php

Ruggeri, Giuseppe. 2003. "Public Expenditure Incidence Analysis," in Handbook on Public Sector Performance Reviews edited by Anwar Shah. (Washington: The World Bank). 
Ruggeri, Giuseppe. 2003. "Public Expenditure Incidence Analysis." Chapter 1 in Handbook on Public Sector Performance Reviews edited by Anwar Shah. (Washington: The World Bank).

Ruggeri, Giuseppe C., Don Van Wart, and Robert Howard. 1994a. "The Redistributional Impact of Taxation in Canada." Canadian Tax Journal 42: 417-51.

Ruggeri, Giuseppe C., Don Van Wart, and Robert Howard. 1994b. "The Redistributional Impact of Government Spending in Canada." Public Finance 49: 212-43.

Ruggeri, Giuseppe C., Don Van Wart, and Robert Howard. 1996. The Government as Robin Hood: Exploring the Myth. (Kingston, ON: School of Policy Studies, Queen's University).

Ruggles, Patricia and Michael O'Higgins. 1981. "The Distribution of Public Expenditure among Households in the United States." Review of Income and Wealth 27, no. 2, pp. 137-164.

Sahn, David E. and Stephen D. Younger. 2003. "Estimating the Incidence of Indirect Taxes in Developing Countries," chapter 1 in The Impact of Economic Poverty and Income Distribution, edited by Francois Bourguignon and Luiz A. Pereira da Silva (Washington: World Bank).

Salanie, Bernard. 2011.The Economics of Taxation. Second Edition. (MIT Press).

Schwab, Robert. 1985.'The Benefits of In-Kind Government Programs." Journal of Public Economics 27: 195-210.

Scott, John. 2014. "Redistributive Impact and Efficiency of Mexico's Fiscal System," in The Redistributive Impact of Taxes and Social Spending in Latin America, edited by Nora Lustig, Carola Pessino, John Scott, special issue, Public Finance Review 42, no.3, pp.368-390.

Selowsky, Marcelo.1979. Who Benefits from Government Expenditures? A Case Study of Colombia. (New York: Oxford University Press).

Shah, Anwar, editor. 2003. Handbook on Public Sector Performance Reviews. (Washington: The World Bank). Shorrocks, Anthony F. 2013. "Decomposition Procedures for Distributional Analysis: A Unified Framework Based on the Shapley Value." Journal of Economic Inequality 11, no.1, pp. 99-126.

Silveira, Fernando Gaiger, Jhonatan Ferreira, Joana Mostafa, and José Aparecido Carlos Ribeiro. 2011. "Qual o Impacto da Tributação e dos Gastos Públicos Sociais na Distribuição de Renda do Brasil? Observando os Dois Lados da Moeda," in: Progressividade da Tributação e Desoneração da Folha de Pagamentos Elementos para Reflexão, edited by. José Aparecido Carlos Ribeiro, Álvaro Luchiezi Jr., and Sérgio Eduardo Arbulu Mendonça. (Brasilia: IPEA) pp. 25-63.

Slemrod, Joel. 1992. "Taxation and Inequality: A Time-Exposure Perspective." Tax Policy and the Economy 6, pp. 105-127.

Smeeding, Timothy M., Peter Saunders, John Cody, Stephen Jenkins, Johan Fritzell, Aldi J. M. Hagenaars, Richard Hauser, and Michael Wolfson. 1993. "Poverty, Inequality, and Family Living Standards Impacts across Seven Nations: The Effect of Noncash Subsidies for Health, Education, and Housing." Review of Income and Wealth 39: 229-56.

Suits, Daniel B. 1997. "Measure of Tax Progressivity." The American Economic Review 67, no.4, pp. 747752.

Tax Foundation, Inc. 1960. “Allocation of the Tax Burden by Income Class.” Project Note No. 45, May. 
Tax Foundation, Inc. 1967. Tax Burdens and Benefits from Government Expenditures by Income Class, 1961 and 1965. (New York: Tax Foundation, Inc.).

Thurow, Lester C. 1971. "The Income Distribution as a Pure Public Good." Quarterly Journal of Economics 85: 326-36.

United Nations Economic Commission for Europe, UNECE (2011), The Canberra Group Handbook on Household Income Statistics, Second Edition, Geneva: UN, https://www.unece.org/fileadmin/DAM/stats/groups/cgh/Canbera_Handbook_2011_W EB.pdf

Urrutia, Miguel and Clara E. de Sandoval. 1976. "Fiscal Policy and Income Distribution in Colombia," in Income Distribution in Latin America, edited by Alejandro Foxley. (Cambridge: Cambridge University Press)

Urzúa, Carlos M. (ed.) 2012. Fiscal Inclusive Development: Microsimulation Models for Latin America (Mexico: IDRC-PNUD-ITESM).

van de Walle, Dominique. 1992. "The Distribution of the Benefits from Social Services in Indonesia, 1978-87.” Policy Research Working Paper 871. World Bank, Country Economics Department, Washington, D.C.

van de Walle, Dominique. 1998. “Assessing the Welfare Impacts of Public Spending.” World Development 26(March): 365-79.

van de Walle, Dominique and Kimberly Nead, eds. 1995. Public Spending and the Poor: Theory and Evidence (Baltimore and London: Published for the World Bank by John Hopkins University Press).

Vermaeten, Frank, W. Irwin Gillespie, and Arndt Vermaeten. 1994. "Tax Incidence in Canada." Canadian Tax Journal 42: 348-416.

Wagstaff, Adam. 2012. "Benefit-incidence analysis: are government health expenditures more pro-rich than we think?” Policy Research Working Paper Series 5234, Washington, DC: The World Bank.

Younger, Stephen D. 2003. "Benefits on the Margin: Observations on Marginal versus Average Benefit Incidence.” World Bank Economic Review 17(1): 89-106.

Younger, Stephen. 2018. "The Impact of Reforming Energy Subsidies, Cash Transfers, and Taxes on Inequality and Poverty in Ghana and Tanzania." In Commitment to Equity Handbook: Estimating the Impact of Fiscal Policy on Inequality and Poverty, edited by Nora Lustig. (Washington, DC: Brookings Institution Press and CEQ Institute). Online version available at http://www.commitmentoequity.org/publications/handbook.php

Younger, Stephen, David Sahn, Stephen Haggblade, and Paul Dorosh. 1999. "Tax Incidence in Madagascar: An Analysis Using Household Data." The World Bank Economic Review 13 (2): 30331.

Younger, Stephen D. and Artsvi Khachatryan. 2017. "Fiscal Incidence in Armenia," in The Distributional Impact of Fiscal Policy: Experience from Developing Countries, edited by Gabriela Inchauste and Nora Lustig. (Washington: World Bank).

Younger, Stephen, Flora Myamba, and Kenneth Mdadila. 2016. "Fiscal Incidence in Tanzania." African Development Review 28, no. 3, pp. 264-276. DOI: 10.1111/1467-8268.12204 
Younger, Stephen, Eric Osei-Assibey, and Felix Oppong. 2017. "Fiscal Incidence in Ghana." Review of Development Economics. Published electronically January 11, 2017. DOI: 10.1111/rode.12299.

Notes 